University of South Florida

DIGITAL COMMONS

Digital Commons @ University of

@ UNIVERSITY OF SOUTH FLORIDA

South Florida

Integrative Biology Books

Integrative Biology

1910

\title{
Asteroids and Ophiuroids of the Aru and Kei Islands: A Translation \\ of Astéries et Ophiures des îles Aru et Kei. Abhandlungen der Senckenbergischen Naturforschenden Gesellschaft, 33: 265-295
}

René Koehler

John Lawrence

University of South Florida, lawr@usf.edu

Follow this and additional works at: https://digitalcommons.usf.edu/bin_books

\section{Recommended Citation}

Koehler, R. (2021). Asteroids and Ophiuroids of the Aru and Kei Islands: A Translation of Astéries et Ophiures des îles Aru et Kei. Abhandlungen der Senckenbergischen Naturforschenden Gesellschaft, 33 : 265-295 (J. M. Lawrence, Trans.). Herizos Press, Tampa.

This Book is brought to you for free and open access by the Integrative Biology at Digital Commons @ University of South Florida. It has been accepted for inclusion in Integrative Biology Books by an authorized administrator of Digital Commons @ University of South Florida. For more information, please contact digitalcommons@usf.edu. 


\title{
Ergebnisse
}

\author{
einer \\ Zoologischen Forschungsreise in den suidöstlichen Molukken \\ (Aru- und Kei-Inseln) \\ im Auftrag
}

der Senckenhergischen Naturforschenden Gesellschaft

ausgeführt von

Dr. Hugo Merton.

Wissensehaftliehe Ergebnisse. 
4069

\title{
ABHANDLUNGEN
}

\author{
HER AUSGEGEBEN
}

VON DELI

\section{SENCKENBERGISCHEN NATURFORSGHENDEN GESELLSCHAFT}

DREIUNDDREISSIGSTER BAND

Hef $t 3$.

INHALT:

Jea n Roux: Reptilien und Amphibien der Aru-"und Kei-Inseln. Mit 2 Tafeln. W. Michaelsen: Oligochäten von den Aru- und Kei-Inseln. Mit 5 Abbildungen im Text. René Koehler: Astéries et Ophiures des îles Aru et Kei. Mit 3 Tafeln.

Ferdinand Pax: Aktinien der Aru-Inseln. Nit 1 Tafel und 1 Karte im Text.

FRANKFURT A. M.

IM SELBSTVERLAGE DER SENCKENBERGISCHEN NATURFORSCHENDEN GESELLSCHAFT 1910

Ausgegeben am 30. Dezember 1910 
Koehler, R. 1910. Asteroids and ophiuroids of the Aru and Kei Islands. A translation of Koehler, A. 1910. Astéries et Ophiures des îles Aru et Kei. Abhandlungen der Senckenbergischen Naturforschenden Gesellschaft. Volume: 33. Pages: 265-295. (J. M. Lawrence, Trans.)

(C) J. M. Lawrence. 2021. Herizos Press, Tampa.

Translator's notes:

Kœhler is spelled Koehler throughout the work.

I thank Janessa Fletcher for preparing the photographs of the plates. 


\title{
Asteroids and Ophiuroids of the Aru and Kei islands
}

\author{
by \\ Dr. R. Koehler \\ Professor at the University of Lyon. \\ (Plates XV, XVI and XVII)
}

Drs. H. Merlon and J. Roux have kindly confided to me the study of the asteroids and ophiuroids that they collected during their scientific voyage to the Aru and Kei Islands. The collection that they sent me, without being very large, has nevertheless a great interest from the zoogeographical point of view as well as the descriptive point of view. The number of new species is seven. The asteroids are represented by eighteen species, of which four are new: an Anthenea, a Pentaceros and two Ophidiaster. Here is the enumeration of them:

Archaster typicus Müller and Troscbel Astropecten granulatus Müller and Troscbel Astropecten pölyacanthus Müller and Troscbel Astropecten scoparius Valenciennes

Luiäia maculata Müller and Troscbel

Craspidaster hesperus (Müller et Troscbel)

Iconaster longimanus (Möbius)

Stellaster Incei Gray

Anthenea Mertoni nov. sp.
Pentaceros Rouxi nov. sp.

Pentaceros turritus Linck

Ophidiaster armatus nov. sp.

Ophidiaster tumescens nov. sp.

Lickia miliaris Linck

Fromia major Koehler

Metrodira subulata Gray

Echinaster purpureus (Gray)

Nepanthia suffarcinata Sladen.

(The species whose names are in bold are new.)

The ophiuroids number twenty-two species, of which three are new, all belong to the genus Amphiura. This genus and the genus Ophiothrix are each represented in the collection by several species as shown in the following list:

Pectinura yoldii (Lütken)
Ophiarachnella infernalis (Müller and
Troscbel)
Ophioglypha sinensis Lyman
Ophiocnida echinata Ljungmann
Ophiactis Savignyi Müller and
Troscbel
Amphiura abbreviata Koehler
Amphiura coacta Koehler

Ophiacantha decora Koehler

Ophiothrix expedita Koehler

Ophiothrix foveolata Marktanner-

Turneretscher

Ophiothrix galatheae Lütken

Ophiothrix longipeda (Lamarck)

Ophiothrix Martensi Lyman

Ophiothrix nereidina Lamarck

Ophiothrix stelligera Lyman

Ophiocampsis pellucida Duncan

Ophiocampsis inermis Koehler 
Amphiura ficta nov. sp.

Amphiura velox nov. sp.

Amphiura accedens nov. sp.

Ophionereis dubia Müller and Troscbel

Euryale Studeri de Loriol.

With the exception of the three forms Fromia major, Pentaceros turritus and Ophiocampsis inermis, found at the Kei Islands, all the asteroid and ophiuroid species cited come from the Aru Islands.

\section{Archaster typicus Müller and Troschel.}

20 April 1908. Dobo. Depth 4 m. Four specimens.

15 May 1908. Dobo. Depth $4 \mathrm{~m}$. Four specimens.

The value of $\mathbf{R}$ varies between 50 and $75 \mathrm{~mm}$. One of the specimens has four arms and another has seven, all equal. In some individuals, the dorsal marginal plates have a variable number of conical tubercles, an arrangement that has often been reported in this species.

\section{Astropecten granulatus Müller and Troschel.}

See for the bibliography:

Döderlein, 1896, Bericht über die von Herrn Prof. Semon bei Amboina und Thursday Islands gesammelten

Asteroidea, in: Semon, Zoologische Forschungsreise, Bd. V, p. 305.

1 April 1908. Karang-guli. Depth 8 to $10 \mathrm{~m}$. One specimen.

$\mathbf{R}=38 \mathrm{~mm} ; \mathbf{r}=9.5 \mathrm{~mm}$.

The specimen is identical to that which Döderlein represented (loc. cit., pl. XVIII, fig. 30 and 30a) and although both do not rigorously conform to the descriptions of Müller and Troschel and of Sladen, I shall follow the example of Döderlein and refer my specimen to A. granulatus, the differences that I observe do not appear to me sufficient to require a specific separation.

I recall that Sladen (Reports of the "Challenger". Asteroidea, p. 215) has corrected the description of Müller and Troschel concerning the dorsal marginal plates that are absolutely unarmed.

In the type of Müller and Troschel, the total diameter is $67 \mathrm{~mm}$ and $\mathbf{R}$ equals $4 \mathbf{r}$. It is a little smaller that mine whose diameter attains 69 to $70 \mathrm{~mm}$. The German authors say that the dorsal marginal plates are higher than wide. In the individual figured by Sladen (loc. cit., pl. XXXV, fig. 3 and 4), the first plates are wider than long, then they are nearly as long as they are wide. On the contrary, In the specimen of Döderlein, the dorsal marginal plates are wider than long and it is the same for my specimen. The ventral marginal plates have some small spines like those that I can see in the photograph reproduced by Döderlein. Marginal spines are very well developed.

The general color is pale brown. The dorsal surface of the disk has in each interradius a triangular deep brown patch. The three or four first dorsal marginal plates of each series are darker than the others. Toward the last third of the arms, we see again a patch on three marginal plates on each side. This pattern is absolutely identical to that of the individual represented by Sladen. 


\title{
Astropecten polyacanthus Müller and Troschel.
}

\author{
Dredging No. 4. 20 March 1908. Wammer. Depth 40 m. A very small specimen. \\ Dredging No. 6. 28 March 1908. Sungi Manubai. Depth 23 m. A specimen of small size.
}

\section{Astropecten scoparius Valenciennes.}

Dredging No. 1. 18 February 1908. Ngaiguli. Depth 14 m. Five specimens.

The length of $\mathbf{R}$ varies from $40 \mathrm{~mm}$ to $12 \mathrm{~mm}$. All the specimens are well characterized. They conform exactly to the description of Döderlein (Zoologischer Anzeiger, Bd. XXVI, p. 326). The marginal spine begins to appear on the fourth or fifth or sixth dorsal marginal plate according to the size of the specimens.

Luidia maculata Müller and Troschel. (PI. XV, fig. 1 and 2; pl. XVI, fig.8 and 9; pl. XVII, fig. 8.)

See for the bibliography:

Koehler, 1895, Catalogue raisonné des Echinodermes recueillis par M. Korotneff aux iles de la Sonde. Memoires de la Soeiete Zoologique de France, 1895, p. 388.

Döderlein, 1896, Bericht über die von Herrn Prof. Semon gesammelten Asteroidea, in: Semon, Zoologische

Forschungsreise, Bd. V, p. 307.

Dredging No. 1. 8 February. Ngaigtili. Depth $14 \mathrm{~m}$. Two specimens.

The two specimens collected are not of very large size. The smaller one has eight arms and $\mathbf{R}$ does not exceed $11 \mathrm{~cm}$. The greatest width of the arms is 13 to $13.5 \mathrm{~mm}$, not counting the marginal spines. The dorsal surface of the arms is strongly convex. I have represented this specimen, seen by the dorsal surface, pl. XV, fig. 1, The other individual has only six arms, of which one is broken and all the others are regenerating. It is larger than the preceding because of the greater width of the arms that attains $18 \mathrm{~mm}$. The dorsal surface of the arms is not vey convex. I have represented the ventral surface, p. XV, fig. 2.

These two individuals have not attained all their development. I have been able to compare them to a specimen belonging to the Museum of Calcutta whose arms, seven in number, pass 35 $\mathrm{cm}$ in length and attain a maximum width of $28 \mathrm{~mm}$ at the base.

The study of these specimens has permitted me to add some complementary information to the descriptions of the authors, notably Müller and Trosche and Perrier, have given on L. maculata. Thus, in comparing the latter species to a new species from the Hawaiian Islands that he describes under the name of L. magnifica, W. K. Fisher (The Starfishes of the Hawaiian Islands, U. S. Fish Commission Bulletin for 1903, part. III, p. 1035) made the remark that neither Müller and Troschel nor Perrier mentioned pedicellariae on the ventral marginal plates of L. maculata and that, probably, the pedicellariae do not exist. He also wonders if the pedicellariae these authors mention on the adambulacral plates are placed after the adambulacral spines or in the middle of them. The descriptions remain quiet on this point. Here is what I observe in this regard in the specimens I have in front of me 
The adambulacral spines, three or four on each plate, are followed by a variable number of pedicellariae with three valves interspersed with some small, very short spines. Sometimes there is only one pedicellaria, sometimes there are two or even three on the two individuals coming from the Aru Islands (pl. XVI, fig. 9). On the individual from the Museum of Calcutta, there are generally three pedicellariae on each plate outside the adambulacral spines (pl. XVII, fig. 8). These pedicellariae are large and strong. In the specimen from the Museum of Calcutta, their length can attain $2 \mathrm{~mm}$. They are rather wide at the base, but their length always exceeds two times their greatest width.

The ventral marginal plates also have pedicellariae that are particularly abundant in the specimen from Calcutta. They are seen preferably between the large marginal spine and that which precedes it, generally two at the same time. We also encounter some, but rarely, between the penultimate spine and that which precedes it. These pedicellariae ordinarily have only two valves. They are also nearly as wide as those of the adambulacral plates, but a little shorter.

In the two individuals from the Aru Islands, the pedicellariae are less numerous and less developed. In the specimen with six arms, I see one nearly constantly between the two large marginal spines. This pedicellaria is always bivalve. In the specimen with eight arms, the pedicellariae are much rarer, but they are found. The bivalve pedicellariae of the specimens from the Aru Islands are less differentiated than in the large individual from the Museum of Calcutta. They resemble more two small spines simply come together.

I have represented in pl. XVI, fig. 8, the paxillae from the dorsal surface of the arms of the individual coming from the Museum of Calcutta.

\section{Craspidaster hesperus (Müller et Troschel).}

Dredging No. 15. 15 April 1908. Sungi Barkai. Depth 7 to $8 \mathrm{~m}$. One specimen. $\mathbf{R}=28 \mathrm{~mm}$; $=9 \mathrm{~mm}$.

\section{Iconaster longimanus (Möbius).}

Dredging No. 14. 14 April 1908. Sungi Barkai. Depth $18 \mathrm{~m}$. One specimen. $\mathbf{R}=57 \mathrm{~mm}$.

\section{Stellaster Incei Gray.}

Dredging No. 11. 3 April 1908. Pulu Bambu. Depth 10 m. Two specimens.

The respective dimensions of $\mathbf{R}$ are 17 and $35 \mathrm{~mm}$.

Anthenea Mertoni nov. sp. (PI. XVI, fig. 1 et 2.)

Dredging No. 6. 28 March 1908. Sungi Manumbai. Depth 23 m. One specimen.

$\mathbf{R}=95 \mathrm{~mm} ; \mathbf{r}=47 \mathrm{~mm}$. 
The value of $\mathbf{R}$ has been evaluated on the ventral surface, measuring the arm up to its end that is raised above. If we measure $\mathbf{R}$ on the dorsal surface, we find a number approximately $20 \mathrm{~mm}$ less.

The body, very robust, is in the form or a star. The sides are strongly concave and the arms are distinct. They are wide, triangular. They rapidly narrow to the end that is obtuse, without forming a thin end as in A. acuta. The body is very thick. Its height attains nearly $20 \mathrm{~mm}$ at the center. The dorsal surface is a little convex. The ventral surface is flat, very slightly sunken at the level of the mouth. The arms are raised a little upwards. The sides of the body are thin at the bottom of the interbrachial arcs where the dorsal marginal plates are very oblique outwards, while their dorsal surface is horizontal on the arms proper where their edges are nearly vertical. The dorsal marginal plates are nearly as wide as the ventral ones and the first ones scarcely protrude below.

The dorsal surface is covered with a thick integument that hides the contours of the underlying plates. We observe on this surface some rounded tubercles, very spaced, not prominent and of small dimensions. The largest does not exceed 1 to $1.2 \mathrm{~mm}$ at the base. These tubercles are arranged in more or less apparent longitudinal rows. We always recognize a distinct regular carinal row and, on each side, two or three lateral rows. In approaching the median interradial line, the arrangement of the tubercles becomes completely irregular. On the interradial lines themselves, the tubercles are completely missing. This results in the formation of five nude bands, with irregular edges, 3 to $4 \mathrm{~mm}$ in width, going from the center of the disk to the bottom of the interbrachial arcs.

The tubercles of the dorsal surface are widely separated from each other. On the carinal line, they occur every 3 or $4 \mathrm{~mm}$. The dimensions of the tubercles decrease rapidly away from the central part of the disk, but they become a little larger toward the interradius. No particular arrangement of tubercles marks the central region of the disk where we see a small, slightly eccentric anus.

Toward the terminal part of the arms, nearly at the beginning of the last third, the arrangement of the tubercles changes abruptly in character. In fact, instead of remaining isolated and separated from each other, they are united, on the contrary, in regularly arranged groups and each of which corresponds evidently to an underlying plate. We distinguish thus a median row that follows the tubercles of the carinal series and has about a half dozen groups. Then, on each side, are two lateral rows. The groups of the first lateral row number seven or eight. They appear a little earlier than those of the median row. Finally, those of the second lateral row appear still a little earlier, but they do not pass the ninth dorsal marginal plate. The two or three first groups that are differentiated contain only several tubercles, but the number of these increases very quickly. While the first groups are separated by rather large intervals, the following ones are very close to each other. The disposition that these tubercles take on the terminal plates of the arms is absolutely identical to that which they have on the adjacent marginal plates and the dimensions are the same. Thus, is differentiated toward the end of each arm, a median row and two lateral rows of plates whose contours remains the same, a median row and two lateral rows of plates whose contours always remain masked by the integument, but whose disposition and limits are indicated by the granules that cover them.

Independently of the principal tubercles I just indicated, we observe others much smaller and visible only with a magnifying glass. These tubercles, intercalated between each other, are not very abundant.

We observe, finally, both on the disk and on the arms, some rather numerous valvular pedicellariae, but always of small size. The larger ones, that are not very abundant, are scarcely 
larger than the diameter of the largest tubercles. Their valves measure $1 \mathrm{~mm}$, rarely $1.5 \mathrm{~mm}$ in length. The other pedicellariae, much smaller and visible with the magnifying glass, are rather abundantly distributed on the dorsal surface. We also find one or two pedicellariae on the plates that are differentiated at the end of the arms.

The result of what I just said is that the dorsal surface of our Anthenea is poorly armed. The large tubercles visible to the naked eye are separated by large intervals and the relatively large pedicellariae are rather rare. It is only in the terminal part of the arms that the tubercles become abruptly numerous and dense and arranged in groups corresponding to the plates of these regions.

The madreporite, rather small, is irregularly oval. The proximal part is widened while the distal part becomes narrower and pointed. It measures $4 \mathrm{~mm}$ by $6 \mathrm{~mm}$. The grooves are numerous, divergent and fine. The proximal edge is found $10 \mathrm{~mm}$ from the anus and the distal end at $24 \mathrm{~mm}$ from the proximal edge of the first dorsal marginal plate.

The dorsal marginal plates, large and wide, are, like the rest of the dorsal surface, covered by an integument that hides the contours. Their limits are indicated only nude intervals. They are not very projecting in general, especially the first ones. After the fourth, they have a slight convex surface. I count thirteen to fifteen according to the arms.

The first plates of each series are oblique as I said above. They are found exactly at the level of the dorsal surface that they continue so that the edge of the body is a little thinned at the bottom of the interbrachial arcs. Also, when we look at the asteroid from above, we see more-or-less the entire width of the first marginal plate. The width attains 8 to $9 \mathrm{~mm}$. The following plates rise progressively. They have a rather high, nearly vertical external surface that connects by a rounded edge to their dorsal surface. This one is much narrower than on the first plates. They measure only 4 or $5 \mathrm{~mm}$ in width. These plates have granules that do not cover the surface completely and leave nude, toward their adjacent edges, a more-or-less wide space. Likewise, the granules do not extend all the way to the ventral edge, so that the row formed by the dorsal marginals is separated from the ventral marginal row by a rather narrow nude band. The first two dorsal marginal plates on each side have scarcely a single transverse row of granules that number five or six. The first dorsal granule is, in general, sensibly larger than the others. It is even larger than the adjacent granules of the latero-dorsal plates. Then the dimensions decrease rapidly as they separate from the proximal border of the plate. Toward the ventral edge, the granules become very fine and ordinarily arranged in two or three rows. The membranous parts thus remain very wide on the edges of the first two plates. On the third, the granules are arranged in a double irregular row in which the dimensions decrease as we approach the ventral edge where the granules also become denser. On the following plates, the granules are more numerous and the nude marginal parts become more and more narrow. But we note then that instead of decreasing regularly from the proximal edge, the largest granules are in the middle region of the plates and then decrease on each side, especially toward the ventral edge where they are always finer and denser than elsewhere. None of these granules reach the size of the first granule that I have reported above on the first marginal plates. On the last plates, the granules are identical to those of the differentiated plates at the end of the arms. The limits between the latter and the row of marginal plate moreover are not very marked.

The dorsal marginal plates can have valvular pedicellariae. but they are never very developed. They do not occur on the first or last plates. The middle plates ordinarily have only one each.

The ventral surface has the ordinary characters of Anthenia. The rather small latero-ventral plates form series parallel to the adambulacrals. The transverse series rejoin the ventral marginal plates. The first two series parallel to the groove are well indicated. The third is still rather distinct and the following are less and less apparent. The plates of the first series are a little wider than 
long. The first measures $4 \mathrm{~mm}$ by $3 \mathrm{~mm}$. They are a little wider than the adambulacrals. Two of them nearly correspond to three of these. I count 26 plates in this first series to the distal edge of the tenth marginal plate. Beyond, the limits are indistinct. Each plate has a large pedicellaria three millimeters in length on the first plates and runs transversely or obliquely in relation to the groove. It is surrounded by a double row of granules, those of the external row being a little larger than the others. This double row is hardly seen o the distal and proximal sides of the plate. On the internal external edges, i.e., at the two ends of the pedicellaria, there is only a single row of granules.

The other plates have a similar disposition, but they become smaller and smaller. At the same time, the difference in size between the two circles decreases and finally disappears. Some of them do not have pedicellariae and are covered uniformly with granules. The pedicellariae are in general oriented in a way that their large axis is directed from the adambulacral to the marginals.

The transverse rows of plates are not very marked in the vicinity of the mediate interradial line, but they become very indicated after the third ventral marginal plate. At the level of the fourth marginal, each transverse row has four latero-ventral plates. At the level of the eighth marginal, there are only two plates per row.

The ventral marginal plates, large and wide, have the same number as the dorsals to which they correspond exactly. They measure from 7 to $8 \mathrm{~mm}$ in width at the base of the interbrachial arcs. They are uniformly covered with rounded granules, dense, a little finer than those of the lateroventral plates which they follow and become a little larger toward the dorsal edge. These granules are also larger on the three or four last marginals than on the preceding. Each plate ordinarily has two small, rather short valvular pedicellariae. Their length does not pass two millimeters and has no determined orientation. Sometimes we encounter only one.

The ambulacral grooves are narrow. The spines of the adambulacral plates are arranged in three rows. The internal spines, to the number of seven on each plate and forming a fan, are not very flattened. The medians are nearly cylindrical with an obtuse and rounded end. These spines are completely hidden in the groove. Those of the second row, located on the ventral surface of the plate, are at first three in number and then two. They are large, cylindrical with a short, rounded and subequal end. Outside is a third, irregular row, generally containing three spines a little shorter than the preceding. The median one is a little longer than the lateral spines.

The teeth do not protrude. The internal adambulacral spines are continued on their free edge, about ten in number. Their dimensions increase progressively up to the end of the tooth. The two external rows of adambulacral spines are continued on the ventral surface of the tooth in the form of a double row of very large and rounded granules that number four or five in the external row and three or four in the internal row.

Similarities and Differences. Anthenea Mertoni is distinguished from A. acuta (Perrier) by its less pointed arms, and from A. articulata (Valenciennes) by its strongly excavated interbrachial arcs. It is closer, by its form, to A. tuberculosa Gray and pentagonula (Lamarck). According to the description of Perrier, A. tuberculosa has very small dorsal and ventral marginal plates and the dorsals are scarcely visible when we look at the animal from above. The tubercles of the dorsal surface are larger on the median line of the arms. The ventral marginal plates are covered with granules surrounding a large pedicellaria, characters that do not agree with those of my species. It is separated from A. pentagonula by the less numerous granules of the dorsal surface, by the arrangement of the granules of the dorsal marginal plates, by the smaller, more numerous lateroventral plates. But A. Mertoni is distinguished from all the other species of the genus by the very particular characters that the dorsal surface take toward the end of the arms where the granules unite into regular groups arranged in series and that appear to correspond to the underlying plates. 
I ask Dr. H. Merton to have the kindness of accepting the dedication of this species.

Pentaceros Rouxi nov. sp. (PL XVII, fig. 1 and 2.)

Dredging No. 6. 28 March 1908. Sungi Manurabai. Depth 23 m. One specimen.

$\mathbf{R}=85-90 \mathrm{~mm} ; \mathbf{r}=34-36 \mathrm{~mm}$.

The disk is very distinct from the arms. It is pentagonal with the sides nearly vertical. The ventral marginal plates protrude below the dorsal marginals in the interbrachial arcs. The corners of the disk are continuous with the arms that begin after the fifth marginal plate. These arms are very thin and slender. They begin to taper very slowly to the end that is rather fine. Their width varies from 14 to $18 \mathrm{~mm}$ at the level of the sixth dorsal marginal plate and from 10 to $12 \mathrm{~mm}$ at the level of the eleventh. Their dorsal surface is rounded and its ventral surface is flat. They are slightly curved toward the ventral side and the ventral surface of the disk is itself concave so that the individual placed on a horizontal surface rests only by the end of the arms.

The dorsal surface of the disk, swollen, has an inconspicuous network of very little projecting narrow trabeculae limiting relatively large poriferal areas. At the points these trabeculae meet are small conical tubercles, always not very developed and that are arranged in the following manner. There are first five apical tubercles occupying the five radial corners of the pentagon. These tubercles, scarcely larger than the others, are approximately $2 \mathrm{~mm}$ in height and $2.5 \mathrm{~mm}$ in width at the base. In each of their intervals is a smaller interradial tubercle. Inside the pentagon, we note some tubercles of the same size as the interradials, a central and three others irregularly arranged. The small anus is located beside the central tubercle. From each apical tubercle leaves a carinal series of tubercles that are first on each carinal plate and then two in two plates only in a rather regular way except toward the end of the arms where the tubercles come closer to each other. The first four or five tubercles of each series only are well formed. They are constituted of small conical eminences having small dimensions and whose size decreases rapidly. The following ones form only small rounded tuberosities that are not very protruding.

Outside the carinal row, we find on each side, a first lateral row of tubercles, to the number of about a half dozen at most and whose dimensions decrease very rapidly. In general. these tubercles remain localized on the disk. Scarcely any of them occur at the base of the arms. Outside the first row, there is only a second that contains only one or two tubercles.

The carinal line of the arms does not protrude and is marked only by the tubercles on its plates.

The plates of the dorsal surface of the disk and the arms are covered with very fine granules, rounded, dense, not very projecting and subequal. These granules extend onto the basal region of the tubercles whose terminal part is nude. Here and there are some valvular pedicellariae but these are always very small and rare.

The poriferous areas have granules, in general many more than the adjacent plates. However, among these small granules, we note other larger ones whose dimensions are nearly those of the granules of the plates. I observe, on the poriferous arears, some very small valvular pedicellariae that are especially seen in the row of areas adjacent to the dorsal marginal plates. There is, in addition, numerous small alveolar pedicellariae, whose two small valves, erect, protrude above the adjacent granules. They are distinguished, when looked at with a magnifying glass, by their pale color that contrasts to the deep brown of the granules. We find these pedicellariae in the same regions in other species of Pentaceros. The poriferous areas of $P$. Rouxi form, on each side, three 
rows. Their dimensions decrease rapidly when arriving at the arms. The external row always encloses areas a little larger than the others.

The madreporite is located immediately outside one of the apical interradial granules, from which it is separated by an interval of at most a millimeter. It is elongated in the form or an ellipse or a lozenge with very rounded corners. It measures $5.5 \mathrm{~mm}$ by $3.5 \mathrm{~mm}$. It has extremely fine grooves, fine, divergent, not very winding and, in addition, a fissure directly obliquely.

The dorsal marginal plates number 21 to 22 on each side. They are small and not very developed. The row that contains them is not very apparent. The internal region of each plate is prolonged in a thin process that is continuous with the network formed by the dorsal ossicles. In the interbrachial arc, the plates are notably wider than long. The narrow a little on the arms because of the reduction of their internal process, but they are still a little wider than long. Their dorsal surface is barely convex. The protrusion they form is not great. However, the first two or three plates of each series are a little more swollen than the others. Likewise, in interradius 3, the first plate has a small very marked conical tubercle. Toward the end of the arms, the plates are little and two or three of them can even make a small obtuse preeminence. All the plates are covered with rounded granules, very dense and vey fine, a little smaller than those of the rest of the dorsal surface. They each have one or two small valvular pedicellariae, always located in the internal region. These pedicellariae are scarcely seen on the first marginal plates that limit the sides of the disk. They disappear in general on the arms.

The latero-ventral plates are small and numerous. They form regular longitudinal and transverse rows, but their limits are absolutely indistinct in the internal half of the interradial areas, on about half its height. In the external half, the contours of the plates become very apparent. We recognize regular transverse rows that reach the edge of the disk and even pass onto its lateral surfaces to reach the ventral marginal plates. In fact, these, as we shall see later, do not reach the ventral surface on the sides of the disk. The latero-ventral plates decrease greatly in size as they approach the edge of the disk. Toward middle of the of the height of the interradial areas, i.e., in the region where their contours begin to become apparent, the largest measure $3 \mathrm{~mm}$ in length by $2 \mathrm{~mm}$ in width. Then they become as long as they are wide and, toward the edge of the disk, they do not pass one mm.

The longitudinal rows become distinct only at some distance from the mouth. The plates of the row that immediately follows the adambulacral correspond exactly to the latter. They are rather large, rectangular, as long as they are wide or a little wider than long. They extend while decreasing progressively in size to the top of the arm. The plates of the second row have at first the same dimensions as the preceding. But they rapidly decrease in size and do not pass the ninth ventral marginal. The following row scarcely passes the base of the arm.

I count about ten transverse rows of plates on each side of the median interradial line, up to the height of the first ventral marginal plates, i.e., up to the first late of each marginal series that is seen on the ventral surface. At this level, the rows each contain four to five plates between the corresponding ventral marginal and the adambulacrals. At the level of the eighth ventral marginal, i.e., a little beyond the beginning of the arm proper, there are only two latero-ventral plates in each row. Beyond, we find no more than one, at least in front of each marginal because, in the intervals of these latter, we see insinuated some small plates that do not make part of a regular alignment.

The latero-ventral plates have rounded plates or made polygonal by reciprocal pressure, not very prominent, to the number of eight to ten on the larger plates and surrounded by a circle of finer granules. The exterior circles are quite contiguous to the adjacent circles. All the granules are very dense. 
In the internal half of the interradial areas, there is a continuous covering of extremely dense granules that hide the contours of the underlying plates. These granules are rounded and unequal. We can often distinguish small groups of some larger granules surrounded by a circle of smaller granules. Sometimes the central granule is raised into a small conical prominence, but this differentiation is, in any case, scarcely indicated.

The valvular pedicellariae are rather numerous in the internal region of the interradial areas. But they are small. Their length does not exceed $1.5 \mathrm{~mm}$. In the external region, they are much less numerous and even smaller. But they do not disappear completely, and we find some still on the small plates of the periphery of the disk. The pedicellariae are seen especially on the plates of the first row parallel to the ambulacrals. Each plate can have three or four of them.

The ventral marginal plates are the same number as the dorsals and they correspond exactly. The line of separation of the two rows is quite apparent on the arms. But it is much less on the edge of the disk. We can find at the bottom of the arcs two or three small supplementary plates between the dorsal marginals and the ventral marginals. In interradius 3, where the first dorsal marginal plate of a series has a small tubercle, the two supernumerary plates in question are even a little convex and slightly protruding.

The first ventral marginal plates of each series, that limit the sides of the disk, are absolutely invisible on the ventral surface. We see them only when we look at the animal by the dorsal surface. These plates are very small, rectangular, very little or not protruding and smaller than the dorsal marginals that correspond to them. The ventral marginal plates develop, in fact, only when they reach the base of the arms, where they appear on the ventral surface. They then become a little larger and higher than the dorsal marginals, because they cover two-thirds of the lateral surfaces of the arms, while the dorsal marginals cover only the upper third. In reaching the arms, the ventral marginal plates become square, nearly as wide as they are long, and even a little higher than wide toward the end of the arms. They are also a little more convex than in the interbrachial arcs. In the last third of the arms, they can even have a small, more-or-less developed tubercle. It is seen on nearly all the plates after the fourteenth and especially attains its development from the sixteenth plate to the twentieth. They are covered with very dense granules that are first identical to those of the dorsal marginals. But they become a little larger on their ventral surface. Some valvular pedicellariae are seen sometimes on the first ventral marginal plates, but they are still less numerous than on the dorsal marginals.

The ambulacral grooves are rather widely open on two arms. The ambulacral tubes are well developed and have a large sucker.

The adambulacral plates have first in the groove an internal row of nine spines, from a triangular comb in which the median spines are much more elongated than the others. These spines are flat. On the ventral surface of the plates are three large protruding spines, flat, with a rounded end, the median a little longer and wider than the others. The number three seen on the first plates then falls to two. In each group, on the oral side, is a pincer pedicellaria. Outside the second row of adambulacral spines, the granules of the adjacent ventral plates often rise as small spines, three per plate, and simulating a third row. These small spines are always less developed than those of the second row. They are separated from the latter by an empty space. The species is thus indeed diplacanthid.

Near the mouth, the spines of the internal row continue, to the number of six to twelve, on the free border of each tooth in increasing their dimensions, especially the first six or seven that become prismatic and very strong. On the ventral surface of the teeth, the spines of the second row 
continue to the number of four or five, but they do not quite attain the development of the preceding.

Similarities and Differences. The determination of this Pentaceros had caused me much difficulty because it is possible the individual is not adult. Nevertheless, it does not appear possible to be referred to any known species. As I said above, P. Mertoni is a diplacanthid form. It is notable for its arms very distinct from the disk, as occurs in some species such as P. decipiens, orientalis, Troscheli, productus etc., by the dorsal position of the ventral marginal plates in the interbrachial arcs, and finally by the considerable number and small dimensions of the latero-ventral plates. The ratio $\mathbf{R} / \mathbf{r}$ varies from 2.5 to 2.7 . These are numbers that are not excessive and that we encounter in many species. But in P. Rouxi, the arms remain narrow for their entire length and they are well separated from the disk at their base. The dorsal and ventral marginal plate are nearly completely lacking in tubercles and spines. However, these appear at the end of the arms, both on the dorsal plates and on the ventrals. The dorsal marginal plates also have a certain tendency to develop tubercles since one of them has a quite apparent one.

$P$. Rouxi is easily distinguished from species with relatively thin arms that I have cited above. Thanks to the kindness of Jeffrey Bell, I have been able to obtain photographs of several species of Pentaceros of the British Museum that, with the excellent descriptions published by the scholar, permit giving an exact account of their characters. Among the species with relatively thin and elongated arms that we know presently, it is with $P$. Troscheli Bell that $P$. Rouxi has the greatest similarity and we could ask if it is not a young form of the first species. The greater development of the marginal spines in the second half of the arms of $P$. Troscheli could be explained by the difference in age. But this hypothesis does not seem sustainable to me. First, P. Troscheli is a triplacanthid species. Moreover, the ventral interradial areas are greatly reduced because of the development of the ventral marginal plates that are very wide and that are not only located on the ventral surface of the body but even are covered above by the dorsal marginals. This is exactly the contrary of what happens in my species. Finally, the five apical spines ae vey developed. In the type of Bell, $\mathbf{R}=140 \mathrm{~mm}$ and $\mathbf{r}=47 \mathrm{~mm}$ and the arms are relatively longer than in $P$. Rouxi.

$P$. orientalis Müller and Troschel, which is very near $P$. Troscheli also has five large apical tubercles and spines on nearly all the marginal plates.

$P$. decipiens Bell also has long, thin arms. But it has no spines on the ventral marginal plates in the second half of the arms. Moreover, it has five large apical tubercles and the latero-dorsal plates have no prominence. As for $P$. chinensis Bell, it is separated from the preceding species by its relatively shorter arms, widened at the bases and decreasing gradually in thickness up to the end. The first dorsal marginal plates alone have spines, while the ventral marginals have them the entire length of the arm. There are also five large apical tubercles.

Among the species with elongated arms, I shall cite again $P$. Wesermanni Lütken that was very kindly sent to me by my excellent friend, Dr. Mortensen. It is a species of large size, has a considerable development of tubercles on the dorsal surface of the body. It has nothing in common with $P$. Rouxi. As for $P$. productus, I have been able to study a specimen of it coming from the Museum of Amsterdam that Professor Max Weber has kindly confided to me. It is in this species that the arms can attain the greatest development and the ratio $\mathbf{R} / \mathbf{r}$ can reach the number 4 . Apical tubercles and those of the carinal line are very small. They are not very developed or even lacking on the latero-dorsal plates. Nearly all the ventral marginal plates have large tubercles and the latero-ventral plates are armed with spines.

In $P$. affinis Müller and Troschel and australis Lütken, whose types I have also been able to study the types that were kindly sent to me, the first by E. von Marenzeller and the second by 
Mortensen. The arms are quite distinct, but they are relatively thick and shorter than in the preceding species. All the dorsal and ventral marginal plates have tubercles. The apical tubercles as well as those of the carinal series are more developed than the others. P. Rouxi is completely different from these two species.

It cannot be confused with $P$. mammillatus Müller and Troschel. Individuals of the same size as the single specimen collected by Merton and Roux have a thick and strong disk that is widely continuous with the arms, which are short and widened. The latero-dorsals of the disk and arms have very developed pointed tubercles, independently of the large apical and carinal tubercles.

From the point of view of the armament of the dorsal surface of the disk and arms, we can find some similarity between $P$. Rouxi and $P$. gracilis Lütken, Lütkeni Bell and hawaiensis Fisher. $P$. gracilis is a triplacanthid species and its arms are continuous widely at their base with the disk. Moreover, the network of dorsal ossicles is very regular and has a tubercle at the meeting points of all the ossicles. All the dorsal and ventral marginal plates have a protruding tubercle. I have compared the specimen from Aru with a $P$. gracilis that I possess in my collection and whose dimensions are rather near $(\mathbf{R}=105 \mathrm{~mm}$ and $\mathbf{r}=39 \mathrm{~mm})$. The two species are completely different. In $P$. Lütkeni, which is diplacanthid, the disposition of the tubercles recall that we observe in $P$. gracilis, but the five apical tubercles are larger than the others. The latero-ventral plates are very distinct.

It is obviously $P$. hawaiensis that $P$. Rouxi is nearest, at least from the point of view of the disposition of the tubercles, but they are more developed in the first species. Moreover, the arms are shorter, wider at the base and less distinct from the disk. The first dorsal marginal plates have a tubercle and the latero-ventral plates have quite different characters. The two species cannot be confused. In the type described by Fisher, the dimensions are $\mathbf{R}=125$ and $\mathbf{r}=50 \mathrm{~mm}$.

I ask Dr. Roux to kindly accept the dedication of this species.

\section{Pentaceros turritus Linck.}

Dredging No. 6. 28 March 1908. Sungi Manumbai. Depth 23 m. Two specimens.

17 April 1908. Wokan. Depth 2 m. A large specimen.

17 June 1908. Nuhu Tawun (Kei Islands). One large specimen.

In one of the individuals from dredging No. 6, in which $\mathbf{R}=95 \mathrm{~mm}$., the tubercles are conical and pointed. In the second, which is smaller $(\mathbf{R}=75 \mathrm{~mm})$, these tubercles are rounded at the top.

The two large specimens have a similar difference: those from the Kei Islands, in which $\mathbf{R}$ measures $120 \mathrm{~mm}$, the large tubercles are rounded, while those in the other, which is larger $(\mathbf{R}=$ $140 \mathrm{~mm}$ ), these tubercles are conical and pointed.

I observe in the poriferous area small alveolar pedicellariae identical to that $\mathrm{I}$ have reported in $P$. Rouxi and that are seen especially on the two small specimens. 
Ophidiaster armatus nov. sp. (PI. XV, fig. 8; pl. XVII, fig. 6.)

Dredging No. 13. 9 April 1908. Sungi Barkai. Depth $15 \mathrm{~m}$. Three specimens.

The three individuals are in very good state of preservation. They measure respectively

\begin{tabular}{ll}
\multicolumn{1}{r}{} & $\mathbf{r}$ \\
50 to $58 \mathrm{~mm}$ & $8 \mathrm{~mm}$ \\
45 to 46 “ & 7 “ \\
$42 \mathrm{~mm}$ & 6
\end{tabular}

In the largest, the arms are more or less rounded. The others are more spread out. These are those that I have photographed and represent in pl. XV, fig. 8 and pl. XVVII, fig. 6.

This disk is small. The arms are cylindrical, with the ventral surface a little depressed, especially in the two small specimens. They grow very progressively from the base up to the end that is rounded. The width of the arms at the base is 9,7 and $6.5 \mathrm{~mm}$ respectively. The rounded end is 3 to $4 \mathrm{~mm}$ in width.

The plates of the dorsal surface of the disk are less distinct on the large individual than on the two others. It is on the smallest that the disposition is the most regular. We distinguish first five rounded radial plates, each of which follows the carinal row of the arms. Then five interradial plates, a little smaller and wider transversally. Iside the circle thus limited, we note another circle of five small radial plates and a little larger centro-dorsal.

The madreporite touches the external edge of one of the interradial plates. It is large, nonprotruding, nearly circular, but slightly pyriform in the middle specimen that measures $2.2 \mathrm{~mm}$ in width by $2.5 \mathrm{~mm}$ in length. In the two others, it is on the contrary a little wider transversally.

From each primary radial leaves a carinal row of trapezoidal plates, having a distal edge wider than the proximal edge and divergent lateral edges, slightly concave and united on the distal side by two narrow corners. In the large specimen, the distal edge measures $2 \mathrm{~mm}$ in width at the base of the arms. Outside this median row is a first row of plates having the same form and nearly the same dimensions as the preceding, then a second row of plates a little smaller that represent the dorsal marginals, and, finally, a last row of still narrower plates representing the ventral marginals. All the plates form very regular transverse rows. I count thirty-five carinal plates on the large individual.

The carinals and the plates of the first two rows of laterals are convex and form a rather apparent protrusion. They are covered with rounded granulations, rather large in the middle of the plate, but becoming finer toward the edges. In the last third of the arm, we see one of the granules in the center of the plate is more developed and forms a very clear small round tubercle that, on the plates of the carinal row and the first lateral row, remains rounded and of small dimensions. But on the other two rows, it develops more to form small spines, short but very strong and having nearly the same length as the external adambulacral spines at this level. As a result of this arrangement, the ends of the arms have several rows of very apparent small spines that give $O$. armatus a particular physiognomy.

The poriferous areas are large and very apparent, rounded or a little widened transversely. They measure more than a millimeter in width at the base of the arms of the large individual. They are seen between the plates of the dorsal surface of the disk. On the arms, they are arranged in eight very regular rows. The two ventral rows, located between the marginal plates and the latero- 
ventrals, are less developed than the others and do not pass the middle of the arms in the small specimen as in the large. In the middle, they appear to be completely missing. At least, I could not find the least indication of them.

The ventral surface of the arms is uniformly covered with rounded and protruding granules, close to each other, at least as large and even a little larger than the largest granules of the dorsal plates. The limits of the latero-ventral plates that they cover are not very apparent and we can scarcely distinguish the transverse lines separating the ventral marginals and the latero-ventrals. Each ventral marginal corresponds to two latero-ventral plates, but it is impossible to recognize the lines of separation between the ventral marginals and the latero-ventrals, the same between the latter and the adambulacrals. Judging by the disposition of the spines, the adambulacral plates are a little shorter than the latero-ventrals.

The adambulacral spines have the same disposition characteristic of the genus Ophidiaster. The two internal spines of each adambulacral plate are erect. They are flat and their end is obtuse. They are arranged a little obliquely in relation to each other. The external and proximal spine is stronger and wider than the internal and distal spine that is very slightly shorter. At some distance on this row is a large spine, widened, conical, with an obtuse point directed outwards and nearly hidden on the ventral surface. This spine is sometimes missing. At the base of the arms, and on approximately the first quarter of its length, the external spines are shorter and denser. On the other hand, it is to be noted that they do not become much shorter toward the end of the arms as usual. They straighten up and contribute, with the spines of the lateral plates to make the end of the arms spiny.

It has been impossible for me to find the least trace of pedicellariae on the three specimens.

The dorsal surface of the body is deep yellowish violet with two of three paler yellowish rings with irregular and little accentuated limits in the last third of the arms. The ventral surface is grayish and has, on is edges, some irregular patches of the same color as the dorsal surface.

Similarities and Differences. O. armatus has a very particular physiognomy. I see no species with which we could confuse it. The presence of small spines at the end of the arms separates it immediately from species such as $O$. asperulus Lürkwn (synonym of $O$. cylindricus Müller and Troschel), helicostichus Sladen and Perrieri Loriol, with which it has some similarities. It resembles especially $O$. Perrieri by the arrangement of the plates. They are distinguished, not only by the terminal spines of the arms, but also by the characters of the adambulacral spines.

It is obvious that our asteroid belongs to the genus Ophidiaster. The adambulacral spines are arranged as in all the species of this genus and the plates form regular longitudinal rows as in the other Ophidiaster. I shall note, in regard to this latter character, that it is not absolutely special to Ophidiaster. In particular, we see it in Linckia marmorata Michelin. This species has been described well by Perrier (Révision des Stellérides, p. 135) and it has been figured by de Loriol who adds some remarks to the description of Perrier (Stellérides de l'ile Maurice, p. 35). The arrangement of the adambulacral spines is that of a Linckia and I do not think that we can remove this species to the genus Linckia to replace it in the genus Ophidiaster where it was first classified by Michelin because of the regular arrangement of the plates. But L. marmorata has some resemblances to $O$. armatatus. It has some particularities that have not been indicated by the authors and it is not perhaps useless to report here.

I have been able to study four specimens of Linckia marmorata. In the largest that is found in my collection without indication of origin, $\mathbf{R}=38 \mathrm{~mm}$. The three others belong to the Museum of Geneva. The respective values of $\mathbf{R}$ are $27,30 \mathrm{ad} 32 \mathrm{~mm}$. The provenance indicated is Maurice. The label does not mention that they were determined by de Loriol, but I think I recognize in an 
inscription in pencil the writing of this scholar. Moreover, the determination of these specimens, the same as mine, cannot leave the least doubt and all four conform well to the descriptions of the authors, except in some small points of detail to which I desire to call special attention.

I have represented in pl. XVII, fig. 7, the ventral surface of my specimen.

The granules of the external adambulacral row are small and found on the greatest part of the length of the arm. But toward the end, instead of gradually decreasing, they become larger at the same time that the elongate slightly. They take thus a slightly oval form recalling the spine of the external adambulacral row of Ophidiaster. As a result, toward the end of the arms of Linckia marmorata, the adambulacral armature is intermediate between those of Linckia and Ophidiaster but closer to the latter genus. This character has not been indicated by the authors. It is very clear in the four specimens I have before me.

Perrier and de Loriol have mentioned, in Linckia marmorata, the presence of large granules that are found in the row of plates below the first poriferous areas and that are seen especially toward the end of the arms. These granules correspond to those that I have reported on the ventral marginal plates of Ophidiaster armatus. But here they are never transformed into spines. Each dorsal marginal plate has also, toward the end of the arms, a similar granule in its middle, but these granules are less numerous and less developed than on the ventral marginals. Finally, the last carinal plates also have some of them. All these granules cause small protrusions at the end of the arms of L. marmorata. Although these never develop spines, they recall however the arrangement shown by Ophidiaster armatus.

The two species are moreover completely different as I have said above. To be convinced of this, it is sufficient to compare the two photographs that I give of the ventral surface of the body in Linckia marmorata (pl. XVII, fig. 7) and Ophidiaster armatus (pl. XV, fig. 8). In the smallest specimen of Ophidiaster, whose ventral surface is reproduced in this latter figure, $\mathbf{R}=42 \mathrm{~mm}$. The arms are not much larger than in the Linckia marmorata (in which $\mathbf{R}=38 \mathrm{~mm}$ ). But they are notably wider and the external adambulacral spines are mor developed. The poriferous areas are also much larger than in the Linckia.

I shall add a word on the subject of these poriferous areas. They form six longitudinal rows in Linckia marmorata and eight in Ophidiaster armatus. But, as I have had the occasion to note above, the ventral areas are missing in the middle specimen of the latter species and the ventral surface recalls, in this regard, that of L. marmorata. These few points of resemblance between the two species are interesting to note. The characters of the adambulacral spines appear to me to have some importance. These spines have, in fact, on the greatest part of the length of the arms of $L$. marmorata, characters of the genus Linckia, but toward the end of these arms, they tend to take the characteristic form of Ophidiaster. If I insist on this fact, it is because the distinction of the genera Linckia and Ophidiaster is not based on very precise characters and we can sometimes have difficulty in referring a species to one or the other of these genera. We tend, in fact, now to no longer attribute the same importance as previously to the presence or absence of poriferous areas on the ventral surface. Thus W. K. Fisher has placed in the genus Ophidiaster a species from the Hawaiian Islands, O. sclerodermis, whose poriferous areas do not go onto the ventral surface. We have seen above that one of three specimens of $O$. armatus collected by Merton and Roux does not have poriferous areas. Following the sample of W. K. Fisher, I shall myself describe below a new asteroid, that appears to me cannot be classified other than in the genus Ophidiaster and that lacks ventral poriferous areas.

The American naturalist scholar characterizes the genus Ophidiaster especially by the arrangement of the adambulacral spines and by the formation of longitudinal rows of the plates of 
the arms. However, in Linckia marmorata, the plates of the arms are arranged in regular longitudinal rows and the adambulacral spines take, at the end of the arms, a form that recalls Ophidiaster. On the other hand, the characters of these spines themselves on the largest part of the length of these arms does not permit placing this species in the genus Ophidiaster. The limits between the two genera thus becomes very difficult to establish, all-the-more so because we cannot use as an absolutely distinctive character, the pedicellariae that are only frequent but not constant in Ophidiaster. Also, despite the tendency that I have reported in Linckia marmorata, I think that the best character to invoke is that furnished by the adambulacral spines. The other characters, regular arrangement of the plates of the arms, presence of pedicellariae and the presence of poriferous areas on the ventral surface have a less capital importance. But they add to the first, in all or in part in most cases and they facilitate thus the classification. ${ }^{1}$

\section{Ophidiaster tumescens nov. sp. (PI. XVI, fig. 3 and 4.)}

Dredging No. 14. 10 April 1908. Sungi Barkai. Depth 18 m. One specimen.

The five arms are a little unequal: $\mathbf{R}=52$ to $56 \mathrm{~mm} ; \mathbf{r}=7 \mathrm{~mm}$.

The disk is small. The arms decrease in width from the base that measures $9 \mathrm{~mm}$ to the end that is not very narrow. The dorsal surface of the disk has unequal plates, very large and so protruding they are almost hemispherical. Their contour is made more-or-less polygonal by their reciprocal pressure. We can ordinarily distinguish a primary radial plate in each radius, but the order is not vey regular and, in one radius the spine is moved to the side to take the place of an interradial. The primary interradials are thus only number four. In the central region, we recognize a rather large plate that is without doubt a centro-dorsal and three other very small plates. All these plates are separated wide and very deep grooves. The primary radials are approximately $3 \mathrm{~mm}$ in diameter.

The madreporite, touching the exterior edge of an interradial, is rather small, triangular. Its surface is flat and it is located at a level a little lower than that of other plates of the disk. It has very fine divergent grooves.

The dorsal surface of the arms has only five longitudinal series of very large plates, strongly convex and separated by deep grooves. The carinal row contains plates larger than the others and wider than long. The proximal edge and the distal edge are straight and parallel. The lateral edges are convex. At the base of the arms, these plates measure on average $3.35 \mathrm{~mm}$ in width by $2 \mathrm{~mm}$ in length. In the last third of the arms, the plate become small and are nearly as wide as long. The last two or three have very small dimensions. I count twenty-eight on the longest arm.

The two lateral rows of each side are formed of smaller plates. They have the same length as the carinal plates but they are narrower so that, contrary to the latter, they are a little longer than wide. The external side is convex. The plates of the first row, i.e., that immediately follow the carinals, disappear rather abruptly a little beyond the first half of the arm. The plates of the second row continue up to the end of the arm, which is formed by a small, triangular apical plate. They represent the dorsal marginals. All these plates are convex, but less protruding than those of the carinal row. They correspond exactly to the latter and are, like them, separated by deep grooves.

\footnotetext{
${ }^{1}$ During the printing of this memoire, a detailed study of Linckia marmorata has been published by Jos. J. Simpson and R. N. Rudmore Brown in: Asteroidea of Portuguese East Africa, Proc. R. Phys. Soc. Edinburgh. Vol. XVTJI, p. 1. 1910.
} 
The dorsal plates of the disk and arms are covered with granules, rather small, flat, unequal, larger in the central region and becoming fine toward the periphery. Except for the plates of the disk and the first carinals, each plate has, in general, a pedicellaria in the form of a salt cellar constructed on the ordinary type. The valves have on their free edge, five small teeth, short and conical. The form of these pedicllariae recalls that de Loriol has figured in O. purpureus. On the carinal plates, these pedicellariae are located nearly transversely on the first lateral row. They are sometimes transversal, sometimes oblique. On the second row, they are on the contrary directed parallel to the long axis of the arm.

The poriferous areas are deeply sunken and rather small. Each area contains from twelve to fifteen pores. There are three rows of these areas on each side. Two only are visible on the dorsal surface. The third row, located between the dorsal marginal plates and the ventral marginals is visible only by the sides or by the ventral surface.

The ventral surface of the arms is narrower than the dorsal surface. It is limited outside by a regular row of plates that correspond exactly to the dorsal marginals. We can consider them as ventral marginals. They are largely submerged by the first. They are slightly convex outside, but their ventral surface is quite flattened. They are separated from each other by shallow grooves They are covered with granules identical to those of the dorsal marginals. Each ordinarily has a pedicellaria near their dorsal border and directed parallel to the long axis of the arm.

There is not the least trace of poriferous areas between the ventral marginals and the lateroventral plates.

Between the ventral marginals and the adambulacrals are found latero-ventrals whose contours are nearly completely hidden by the larger granules. They are a little more protruding than those of the ventral marginals. We recognize with difficulty two rows of these plates at the base of the arms. The external rows reach the eighth ventral marginal plate. Several of the plates of the internal row has a salt cellar shaped pedicellaria, near the ambulacral groove and arranged parallel to the latter.

The adambulacral plates are narrow. Two of them correspond ordinarily to one latero-ventral plate, at least at the base of the arms. their spines are arranged in two rows. The internal row has, per plate, two flat spines, erect, short with a rounded edge and located one after the other. The external row has only a single thick spine, fusiform with a blunt end, lying down on the ventral surface of the plate.

Similarities and Differences: Despite the complete absence of pores on the ventral surface proper, it does not seem to me we can hesitate to place this asteroid in the genus Ophidiaster. Its adambulacral spines have the characteristic arrangement of this genus. The plates of the arms are arranged in very regular longitudinal series. And finally, there are salt-cellar shaped pedicellariae like those we know in most of the species of the genus. I have had the occasion to recall above that W. K. Fisher has likewise placed in the genus Ophidiaster a species from the Hawaiian Islands, O. sclerodermus, also lacking ventral poriferous areas.

O. tumescens is very remarkable for the small number of rows the brachial plates formed by the plates, by the large size of these plates and by the considerable protrusion they have on the free surface. They recall by the arrangement of plates another species of the Hawaiian Islands, $O$. triseriatus Fisher, but it is, in any case, much smaller than the specimen collected by Merton and Roux (R measures only $18.5 \mathrm{~mm}$ ). There can be no confusion between the two species.

$O$. fuscus (Gray), which has strongly protruding plates, is also very different from $O$. tumescens. 


\section{Linckia miliaris (Linck).}

Dredging No. 16. 16 April 1908. Udjir. Depth 10-14 m. Two specimens.

The individuals ae the same size. Both have five qual arms. The value of $\mathbf{R}$ varies from 90 to $95 \mathrm{~mm}$. One of the specimens sometimes has, outside the external row of adambulacral granules, another identical row that appears in some places to be maintained for a variable length and then disappear to appear again further on.

\section{Fromia major Koehler. (PI. XV, fig. 7; pl. XVI, fig. 6 et 7.)}

Fromia major Koehler, 1895. Catalogue raisonné des Échinodermes recueillis par M. Korotneff aux iles de la Sonde. Mem. Soc. Zool. France, 1895, p. 399.

North coast of Little Kei Island. Xubu Tawun. 16 June 1908. Three specimens.

Two of the specimens have equal arms. Their respective dimensions are the following: $\mathbf{R}=56$ and $48 \mathrm{~mm} ; \mathbf{r}=12$ and $9 \mathrm{~mm}$.

The largest individual is nearly the same size as the type coming from the Sunda Islands. The other is a little smaller. These two specimens conform very well to the description I gave of the species in 1895 and I have little to add.

The granules that follow the external adambulacral spines have a variable development. Sometimes they are notably larger than the granules covering the adjacent latero-ventral spine, sometimes they are hardly greater in dimensions. In the individuals collected by Korotneff, these granules are particularly developed and prominent. This is why I wrote in 1895 that the adambulacral species were arranged in three rows, those of the external row being rather large granules making a transition to the granules of the latero-ventral plate. According to what I see in the individuals collected by Merton and Roux (pl. XVI, fig. 6), it is more correct to say that there are two rows of spines on the adambulacral plates and that outside these are granules, variable in size and number, that pass progressively to the granules of the ventral plates.

The specimens from the Kei Islands are in an excellent state and the very fine granules of the dorsal surface are very well preserved. They are less so in those of the Sunda Islands. This circumstance explains why they have an arrangement that I had not noted in 1805, that each papular pore is surrounded by a circle of granules larger than the adjacent ones (pl. XVI, fig. 7).

The third individual is very curious. It has some interesting anomalies. It has six unequal arms. Three of these arms are larger and are nearly equal in length. They measure 30 to $35 \mathrm{~mm}$ from the mouth to the end. We can see, in the reproduction in photograph of this specimen that I give in pl. $\mathrm{XV}$, fig. 7, that the six arms are arranged regularly around the disk, the three large ones form, in a way, one distinct group, opposed by a group formed by three small ones. We have the impression, briefly, that an individual reduced to three arms, and being in a state of regeneration, has formed three new arms instead of two that would have been the normal number. But the individual has another very remarkable peculiarity. It has two madreporite plates and, a surprising thing, these two plates are not identical. One of them is located nearly equidistance between the center and he edges. I consider it the normal madreporite plate although it is larger and more protruding that in the specimens with five arms and that its numerous grooves are less fine and more irregular than usual. It measures $3 \mathrm{~mm}$ by 2 . The second plate is contiguous to the dorsal marginals. It is rounded. 
Its diameter is approximately $3 \mathrm{~mm}$. It is not protruding, but its grooves ae less numerous and they are limited by protrusions coarser and more irregular than on the first plate.

By all the other characters, this abnormal specimen conforms to the other $F$. major and there can be no question of separating it from this species.

The specimens in alcohol have kept a gray-violet color, more marked on the largest specimen and on that with six arms. The other is simply grayish.

F. major is still known only by the specimens that Korotneff collected from the Sunda Islands and its discovery at the Kei Islands is very interesting.

\section{Metrodira subulata Gray. (PI. XV, fig. 3; pl. XVII, fig. 3, 4 and 5.)}

Metrodira subulata, Perrier 1875. Révision des Stéllerides, p. 180.

Metrodira subulata, Viguier 1879. Anatomie comparée du squelette des Stéllerides Arch. Zool. Exp., (I), Vol. III. p. 170.

Metrodira subulata, J. Bell 1884. Report on the Zoological collections made during the voyage of "Penguin". Proc. Zool. Soc. London, 1894, p. 394.

Metrodira subulata, Farquhar 1896. Echinoderm fauna of New Zealand. Proc. Linn. Soc. New South Wales, 1898, 12.

Scaphaster Humberti, de Loriol 1899. Notes pour servir ä l'étude des Écliinodermes. VII. Mém. Soc. Sc. Phys. Nat. Genève, Tome XXXIII, p. 27, pl. III, fig. I.

Dredging No. 8. 31 March 1908. Meriri. Depth 6-10 m. One specimen.

According to what I have seen in the single specimen possessed by the Jardin des Plantes of which Perrier has given a description as well as the two photographs that I have been able to make, thanks to the kindness of $\mathrm{J}$. Bell of the British Museum, of one of the specimens of that establishment, it seems to me that the dorsal surface of the specimen from the Aru Islands has more numerous and denser spines than usual. It results in an appearance a little different that recalls rather that of Echinaster. I would have even had some difficulty in relating this individual to $M$. subulata if I had not found in an important collection of asteroids of the Museum of Calcutta, which Dr. Annandale confided to me to study, a rather numerous series of $M$. subulata that has shown me all the transitions between the individuals completely conforming to those of the British Museum and the Jardin des Plantes and others with more or less numerous spines. These individuals are all smaller than those of the Aru Islands.

As M. subulata is very little known, I think it is necessary to give here a detailed description of the specimen collected by Dr. H. Merton. But the integument that cover the spines being rather thick, it is impossible to recognize on the specimen preserved in alcohol, the contours of these latter as well as the origin of the spines, arrangements that we often see well only in dried specimens or even treated with potash. It was undesirable to destroy the single specimen sent to me. I have used, to complete my description, one of the individuals of the Museum of Calcutta that I have dried. In this specimen, $\mathbf{R}$ measures $38 \mathrm{~mm}$.

The five arms are slightly unequal: $\mathbf{R}$ varies between 60 and $65 \mathrm{~mm}, \mathbf{r}=9 \mathrm{~mm}$. The distance between the ends of two non-consecutive arms is $120 \mathrm{~mm}$. (Pl. XVII, fig. 4).

The arms are slender and elongated, subcylindrical, with dorsal and ventral surfaces slightly flattened. Their width is 8.5 to $9 \mathrm{~mm}$ at the base. They taper gradually to the end that is narrow and obtuse. The dorsal surface of the disc and the arms have small spines, short and conical, not abundant on the disk, more numerous on the arms and located without apparent order. These spines, rather sharp, are sometimes isolated, sometimes united in small groups of two, three or 
four. They are irregularly arranged without forming longitudinal rows. The base of these spines is sunken into the integument. It is impossible to recognize the underlying plates that are also covered by the integument. Between the spines are rather numerous papulae, large and isolated, limited by a membranous little projecting rim. They become less numerous toward the end of the arms. The sometimes form longitudinal rows. At least there are on each side of the arms, two longitudinal rows of rather distinct papillae, but in the interval, the papulae are more irregularly arranged.

Papulae also occur on the dorsal surface of the disk where they are smaller. The central anus is very apparent. The madreporite, located near the center of the edge, is rounded and measures 2 $\mathrm{mm}$ in diameter. It is rather protruding. Its edge is extended in some small prominences from which leave a few internal lamellae that limit the rather wide grooves going first in a straight line toward the center and then becoming sinuous.

Because of the presence of these numerous small spines and their union in small groups, the dorsal surface of the asteroid has, at first glance, no resemblance to the genus Metrodia but recalls absolutely an Echinaster such as E. eridanella. But we are quickly struck by the fact that interradial regions of the disk lack spines and thus form five nude bands that are a little depressed, going from the anus to the base of the interbrachial arcs. We note also that the spines appear only on the dorsal surface at the base of the arms and are lacking on the lateral surfaces that remain nude. It is only at some distance from the base, at approximately two or three centimeters, that the spines appear on the sides of the arm. They continue up to the end. On the lateral parts, we see rather clearly across the integument, a dorsal row of rectangular plates arranged very regularly, then along the ventral edge of the arm, a row similar to the preceding. These two rows are at first separated by a row of triangular plates alternating with each other, to which are added some small supplementary plates at the base of the arms. These lateral and marginal plates lack spines at first. They appear only at some distance from the base.

In order to have a more complete idea of the structure of our asteroid and especially of the arrangement of the plates, it is good to describe a dried specimen (Pl. XV, fig. 3; pl. XVII, fig. 4 and 5). We recognize, then, on the disk and in a more-or-less clear manner, five small radial plates, rectangular, a little longer than wide, and five larger, rounded interradial plates. Each plate has some small conical spines, located ordinarily toward the proximal edge. In the central region is a large, rounded plate, on the edge of which is found the anus, then some small plates with absolutely indistinct edges. Outside the primary interradials, we find in each interradius, two smaller plates that have one or two spines only, always located on their exterior side. Following are some completely nude plates that we shall study with the skeleton of the arms.

The madreporite, relatively large and protruding, is near the center of the disk, from which it is separated by a space hardly equal to its width. Its edges end in a circle of small conical prominences comparable to small spines, to the number of about a dozen and corresponding to the internal wall that divide the plate into as many sinuous grooves.

On the arms, the plates are irregularly rectangular and touch each other by their edges except at the points of the papulae. They even have a slight tendency to overlap. They are nearly as long as they are wide. The largest measures approximately one millimeter. They are rather regularly arranged and form, on the dorsal surface, six more or less distinct longitudinal rows that alternate between them. Each has, on its distal edge, a variable number of short spines, but rather thick and conical with a rounded end. Their surface is rugose and covered with fine asperities. It can have two to four and even five spines per plate. When we look at the arm from the side, we see along the dorsal edge, a very regular row of rectangular plates arranged one after the other and larger than the dorsal plates of the arms. These are the dorsal marginal plates. The first of each row is a 
little more developed than the others. It is rounded and oval. On the median interradial line, it touches its congener of the other arm to form, with the dorsal surface of the disk, the base of the interbrachial arcs. The following plates have at first only one or two inserted on their dorsal edge. Toward the fifth or sixth, we see appear a similar spine on the ventral and distal edge of the plate. These plates form, on the lateral surfaces of the arms and the dorsal side, a very regular row in which they are always larger and take a more regular form than the dorsal plates at the same level. We hardly distinguish this row when we look at the asteroid from above because we see then only the spines of the upper edge of the plates.

Below this very regular dorsal marginal row are, in the middle of the lateral surfaces, other plates that simply alternate with each other. These plates are triangular, with rounded corners and edges. After one plate whose top is directed downward, there is another whose top is directed upward. These plates, well developed at the base of the arms, become smaller and smaller and disappear completely toward the first third or ever toward the halfway point of the arm. The first never have spines. It is very rare that the others have one. Immediately in the vicinity of the base of the arms, we see some small, rounded plates intercalated between the triangular plates, giving thus the indication that the alternate series can be doubled into two distinct rows.

Finally, below this lateral series, is a row of ventral marginal plate that occupy the ventral edge of the arms and encroach somewhat onto the ventral surface. These plates are completely comparable to those of the dorsal marginal row reported above. They are, like the latter, regularly rectangular, generally a little longer than wide, and with rounded corners. The row they make is also very regular. With the exception of the first, each plate has in general on its distal edge, two small conical spines. one at the dorsal corner, the other at the ventral corner. The ventral marginal row is separated from the dorsal row for the first third or first half of the arm by the alternate lateral plates that occupy the sides. But, when these latter have disappeared, the two series are joined. We can confirm then that the plates of each series have the same number but that they alternate with each other.

This information permits us to understand the structure that we have noticed in the specimen from the Aru Islands. We see the nature of the five nude interradial bands that we see on the disk, as well as the elongated spaces lacking spines that occur at the base of the arms are continue for some distance. Despite the much larger size of the specimen, we see that the lateral plates separating the dorsal marginal from the ventral row keep the alternate arrangement that we know. However, we note here in each interbrachial arc, between the ventral marginal row and the lateral row, a supplementary row of approximately 5 plates, of which the median one is interradial, that is the rudiment of a second lateral row. It should also be noted that the spines appear on all these plates much further from the base of the arms in the small individual. In fact, these do not appear ordinarily before the eighth in the dorsal and ventral marginal rows and even further in the lateral row. As a result, the nude spaces extend much further in the large specimen than in the small.

The ventral surface of the body is entirely formed by the ventral marginals and the adambulacral plates that immediately follow them. These latter are rectangular, rather wide, and their length is less than their width. Three of them ordinarily correspond to two ventral marginals. Each plate sends a kind of transverse, horizontal apophysis into the interior of the groove. It has on each of its proximal and distal corners, a rather strong and conical spine. The two spines of each apophysis are strongly divergent. They are found nearly opposite from each other in a plane parallel to the axis of the groove. On the stem of the apophysis, are one and sometimes two small vertical spines. In addition, on the free edge of the plate are also two spines stronger than the preceding, short and conical. These two spines are arranged obliquely in relation to each other. 
The external and distal spine is ordinarily larger and wider at the base than the proximal and internal spine. Finally, toward the external edge of the plate and in its middle, we note a spine stronger than the preceding, conical and with a widened base. This spine is found a little separated from the others. It is also separated by a groove that is particularly wide and well-marked in the specimen from the Aru Islands. All the adambulacral spines have an obtuse end covered with very fine asperities.

The adambulacral grooves are very narrow, nearly completely closed because of the closeness of the spines that more-or-less mesh with each other. We recognize however two rows of suckers.

On the teeth, the spines of the free edge of the adambulacral plates elongate rapidly in becoming cylindrical and pointed. They number three or four on each side.

I shall return to Metrodira subulata in a work that I am finishing at this moment on the littoral asteroids collected by the "Investigator" in the Indian Ocean. It will be noted that I have placed in the bibliography of M. subulata, and as a synonym of this species, the Scaphaster Humberti of de Loriol. We can be convinced, in fact, according to the description and figures of de Loriol, that this latter form is nothing other than a M. subulata with sparse spines. I have in addition been able to study the original specimen of de Loriol that is found in the Museum of Geneva to assure myself that it is indeed a M. subulata.

\section{Echinaster purpureus (Gray).}

Dredging No. 16. 16 April 1908. Udjir. Depth 10-14 m. Four specimens.

Two individuals have six subequal arms and two others have five.

\section{Nepanthia suffarcinata Sladen.}

Nepanthia suffarcinata Sladen, 1888. On the Asteroidea of the Mergui Archipelago. Linn. Soc. Journ., Zoology, vol. XXI, p 328, pl. XXVIII, fig. 9 et 10.

Dredging No. 13. 9 April 1908. Sungi Barkai. Depth 15 m. Two specimens.

The respective dimensions of $\mathbf{R}$ are 32 and $22 \mathrm{~mm}$. The larges individual is thus smaller than the type of Sladen in which $\mathbf{R}$ was $48 \mathrm{~mm}$. I note that the arms are not sensibly wider at the base. This difference is perhaps due to the young age of the subjects, but all the other characters conform to the description and figures of Sladen.

The type comes from Owen Island (Mergui).

\section{Pectinura Yoldii (Lütken).}

Ophiopeza Yoldii Lütken, 1856. Bidrag til Kundskab om Slangestjernerne. Vid. Meddel. 185G, p. 9.

Ophiopeza Yoldii Lütken, 1859. Addimenta ad historiam Oplmiroidarum, part. II, p. 98.

Ophiopsammus Yoldii Lütken 1869. Addimenta ad historiam Ophiuroidarum, part. III, p. 98.

Ophiopeza Yoldii Lyman, 1874. Ophiuridae and Astrophytidae, old and new. Bull. Mus. Comp. Zool. Vol. III, part. 10, p. 221.

Ophiopeza Yoldii Lyman, 1882. Reports of the "Challenger". Ophiuroidea, p. 12.

Ophiopeza conjungens Bell, 1884. Report of Zoological collections . . . of of "Alert", p. 137. 
Ophiopeza conjungens Döderlein, 1896. Bericht über die von Herrn Prof. Semon bei Amboina and Thursday Islands gesammelten Asteroidea, in: Semon, Zoologische Forschungsreise, Bd. V, p. 281

Ophiopeza Yoldii Verroll, 1899. North American Ophiuroidea. Trans. Connecticut Acad., vol. X, p. 373.

Ophiopeza conjungens Koehler, 1905. Siboga Expeditie. Ophiures littorales, p. 12.

Ophiopeza Yoldii Lyman Clark, 1908. Notes on some Australian and Indo-Pacific Echinoderms. Bull. Mus. Comp. Zool. Vol. LH. No 7, p 119.

Dredging No. 1. 15 February 1909. Ngaigui. Depth $14 \mathrm{~m}$. Three specimens.

Dredging No. 6. 28 March 1908. Sungi Manubai. Depth 23 m. Several specimens.

Dredging No. 11. 3 April 1908. Pulu Bamfou. Depth $10 \mathrm{~m}$. One specimen.

Dredging No. 14. 10 April; 1908. Sungi Barkai. Depth 18 m. Six specimens.

Lyman Clark has been able to establish (loc. cit.) that Ophiopeza conjungens, descried by Bell in 1884 and that different authors have since cited after this period, was in reality not different from Ophiopeza Yoldii that Lütken had made known in 1856. This defiled species appears to have been forgotten, at least we did not suspect it would be encountered in the Indo-Pacific domain because the Danish author indicated the Antilles as the homeland of $O$. Yoldii. Verrill, in 1899, also reported $O$. Yoldii among the ophiuroids of the Antilles, but there is evidently an error.

In the very scholarly study that he devoted to the genera Pectinua, Ophiopeza, Ophiopezella etc., Lyman Clark rewrote the limits of these genera and, according to his nomenclature, the species that concerns us should be placed in the genus Pectinura. I willingly accept the classification of Lyman Clark although it presents some difficulties. Thus, the genus Ophiopeza is suppressed and most of the species placed until now in this genus go into the genus Pectinura in the new meaning attributed to it by L. Clark, while most of the species of the old genus Pectinura are placed in the new genus Ophiarachnella.

\section{Ophiarachnella infernalis (Müller and Troschel).}

(Pectinura infernalis auct.)

See for the bibliography:

Pectinura infernalis Koehler, 1905. Siboga Expeditie. Les Ophiures littorales, p. 12.

Pectinura infernalis Lynian Clark. 1908. Some Japanese and East Indian Echinoderms. Bull. Mus. Comp. Zool. Vol. LI, No. 11.

Ophiarachnella infernalis Lynian Clark, 1909. Notes on some Australian and Indo -Pacific Echinoderms. Ib.. vol. LII, No. 7, p. 124.

Dredging No. 17. May 1908. Sungi Manumbai. Depth $20 \mathrm{~m}$. One specimen.

In his work of 1909, Lyman Clark united with Pectinura (Ophiarachnella) infernalis, P. similis that I had described according to some individuals collected by the "Siboga" (loc. cit. p. 12). He invokes, in favor of this point of view, the variations that he observed in the size, the number and position of the nude plates on the disk as well as in the number of brachial spines of $P$. infernalis. The study that he did had thirty-seven specimens of $P$. infernalis belonging to the Museum of Comparative Zoology. But while pointing out the variations, he added that none of his specimens conform exactly to the type of $P$. similis. He notes only that some of them have eleven brachial spines and that others approach $P$. similis by characters of the dorsal plates and of the radial shields. 
I have already noted, in my description of $P$. similis, that this species is very close to $P$. infernalis and that it can be easily confused with the latter. I have recalled this affinity in the specific name that I gave it. I shall even add that I had some little hesitation in creating this species. If I created it, it is because I have found in the collection of the "Siboga" no transition forms with $P$. infernalis. Lyman Clark noted I reported the two species in the same stations. This fact appeared to me very important because, both among individuals coming from different stations and between individuals of the same stations, the two forms always show themselves as different from one another. I have been able, from the moment I undertook the study of these two forms of Pectinura to establish two perfectly distinct lots containing one, $P$. infernalis, the other $P$. similis. That I have done without the least hesitation without encountering a single specimen that was somewhat doubtful. The appearance of the two species was rather different at first glance. The only question that caused me difficulty was to know if there was reason to create a new species or to make of the form that I distinguished so easily from P. infernalis, a simple variety of the latter. If I decided to make a new species, it is as I said above, because if I have not been able to discover among the numerous specimens that I have had before me, any intermediary form with $P$. infernalis.

If transition forms exist, it is indisputable that $P$. similis should disappear as a species. I am quite disposed to adopt the opinion of my American colleague. I shall make, for the moment, only a slight reservation, because the question appears to me not absolutely decided because Lyman Clark has not found, in all the series he has examined, a single specimen identical to my $P$. similaris but only some individuals approaching the latter form.

Moreover, these discussions on the value of the words species and variety have no great importance. We describe forms and it is convenient to apply names to them. Often insufficiency of documentation leads us to give to some individuals a specific name that the study of more complete material would lead to suppression. But all the differences and particularities on which we had based a separation still exist and these are what it is important to note.

\section{Ophioglypha sinensis Lyman.}

Dredging No. 4. 19 March 1908. Wammer. Depth 50 m. One specimen.

Dredging No.6. 28 March 1908. Sungi Manumbai. Depth 23 m. Three small specimens.

Dredging No. 13. 9 April 1908. Sungi Barkai. Depth 15 m. Two specimens.

Dredging No. 17. 5 May 1908. Sungi Manumbai. Depth 5 m. One specimen.

\section{Ophiocnida echinata Ljungmann.}

Dredging No. 2. 19 February 1908. Ngaiboor. Depth 14 m. One specimen. Dredging No. 8. 31 March 1908. Meriri. Depth 6-10 m. One specimen.

\section{Ophiactis Savignyi Müller and Troschel.}

Dredging No. 2. 19 Feruary 1808. Ngaiboor. Depth 14 m. One specimen. Dredging No. 13. 9 April 1908. Sungi Barkai. Depth 15 m. Two specimens. Dredging No. 16. 16 April 1908. Udjir. Depth 10-14 m. One specimen. 
All the specimens have six arms and are of very small size.

\section{Ophionereis dubia Müller and Troschel.}

Dredging No. 2. 19 February 1908. Ngaiboor. Depth $14 \mathrm{~m}$. One small specimen.

Dredging No. 14. 14 April 1908. Sungi Barkai. Depth 18 m. One very small specimen.

Dredging No. 17. 5 May 1908. Sungi Manumbai. Depth 5 m. One specimen.

\section{Amphiura abbreviata Koehler.}

Amphiura abbreviata Koehler, 1905. Siboga Expeditie. Les Ophiures littorales, p. 33.

Dredgng No. 17. 5 May 1908. Sungi Manumbai. Depth $20 \mathrm{~m}$. One specimen.

Diameter of the disk $4,5 \mathrm{~mm}$; length of the arms 25 to $20 \mathrm{~mm}$.

This specimen differs from the type by it buccal shields that are a little shorter. But the other characters conform so well that it appears to me not possible to separate them. It is a little larger and the arms are a little longer than the type.

A. abbreviata was encountered by the "Siboga" at the Paternoster Islands, at the anchorage of North Ubian and at Jedan (Aru Islands). The individual collected in the latter location, very near consequently to that where Merton and Roux found this species is alone in good condition. It served me as the type to describe this Amphiura.

\section{Amphiura coacta Koehler.}

Amphiura coacta Koehler, 1905. Siboga Expeditie. Les Ophiures littorales, p. 34.

5 May 190S. Sungi Kololobo. Depth $5 \mathrm{~m}$. One specimen.

The two specimens according to which I established this species in 1905 were collected by the "Siboga" at the anchorage of Tual (Kei Islands).

In the specimen of Merton and Roux, the diameter of the disk measures $5.5 \mathrm{~mm}$. The arms are 25 to $30 \mathrm{~mm}$ in length. The arms ae relatively a little longer than in the type. The external lobe of the buccal shields is wider and a little more developed. All the other characters conform absolutely.

Amphlura ficta nov. sp. (PI. XVII, fig. 9 and 10.)

Dredging No. 6. 28 March 1908. Sungi Manumbai. Depth $23 \mathrm{~m}$. Three specimens

Dredging No. 14. 10 April 1908. Sungi Barkai. Depth $18 \mathrm{~m}$. Two specimens.

All the specimens are of very small size. The diameter of the disk does not exceed $2 \mathrm{~mm}$. The arms, five in number, are not more than 12 to $13 \mathrm{~mm}$ in length.

The disk is rounded, little or not concave in the interradial spaces. The dorsal surface covered with plates of medium size, imbricated, a little smaller in the central part and becoming a little larger toward the radial shield. There is not the least indication of primary plates. The radial shields 
ae large, elongated, three times longer than wide, with a convex external edge, very near or even contiguous on the outside, separated inside by a row of plates. Their length is nearly equal to half the disk radius.

The ventral surface of the disk is covered with extremely fine plates but, however, quite recognizable and visible on its entire extent. The genital slits are very narrow. The buccal shields are triangular with rounded corners. The distal edge is also rounded and has in its middle a moreor-less marked prominence. They are wider than long. The adoral plates are rather small, very narrow inside and widened outside. They are contiguous on the median line. The oral plates are small. The buccal papillae are two in number. The external one is elongated and conical with a blunt end. The internal one is very large and very wide. A small conical papilla occurs outside on the upper plane.

The dorsal brachial plates are very large, with a very wide and rounded distal edge. It is connected by equally rounded corners to the lateral edges that are divergent. The proximal side is narrow. These plates are as wide as they are long or a little wider than long.

The first ventral brachial plate is very small, triangular, constricted between the adoral plates. The following ones are large, quadrangular, with rounded corners. They remain longer than wide for the entire length of the arm.

The lateral plate, little prominent, have first six, then five spines. The first ventral is cylindrical with a rounded end. It passes the article. The others are shorter, rather then and have very fine rugosities at their end. All these spines are near each other.

The single tentacular scale is small and oval.

Similarities and differences. A. ficta belongs to a group of Amphiura s. str. having plates on the two surfaces of the disk and a single tentacular scale. We can ask if the individuals collected are adults. This appears rather probable because they are all the same size. In any case they cannot be related to any known species.

A. ficta is near A. Duncani, but it is distinguished from it by the first ventral spine longer than the others. It is likewise distinguished by the same character and by the form of the external buccal papilla from A. constricta Lyman. Finally, it is separated from A. abbreviata, celata and coacta that I have described according to specimens collected by the "Siboga" in the nearby areas by the form of the buccal shields.

\section{Amphiua velox nov. sp. (PL XV, fig. 6; pl. XVI, fig. 5.)}

Dredging No. 4. 20 March 1908. Wokam. Depth 40 m. Two specimens.

The diameter of the disk is $4.5 \mathrm{~mm}$. The six arms measure approximately $30 \mathrm{~mm}$.

The disk is rounded, very slight concave in the interradial spaces. The dorsal surface has rather deep incisions at the insertion of the arms. They have very fine and imbricated plates, smaller in the central region and becoming larger in the vicinity of the radial shields. There is not the least indication of primary plates. The radial shields are very elongated, four times longer than wide, with a straight internal edge, a pointed proximal end and a straight and narrow distal edge. They are contiguous on the outside, divergent inside and separated by several rows of plates.

The ventral surface of the disk is completely covered by fine and imbricated plates. The genital slits are narrow.

The buccal shields are elongated and pyriform, a little longer than wide, with a sharp proximal corner with a rounded end and a convex distal edge more-or-less prominent in the interradial space. 
The adoral plates are elongated and strong, with a strongly concave free edge. The oral plates are rounded, a little longer than wide. The buccal papillae number two. The external papilla is large and strong, thick, cylindrical. Its end is obtuse and often swollen. Sometimes this papilla is widened and flattened and even split into two smaller ones. The terminal papilla is wide and thick. Toward the point of union of the adoral and oral plates, we see on a more elevated plane, a small, cylindrical and very short scale.

The dorsal brachial plates are extremely large, with a proximal side narrower than the distal side that is widened, strongly convex and connected by rounded corners to the lateral edges that are obliques and not very distinct. They are a little wider than long.

The first ventral brachial plate is widened inside. The following ones are large and quadrangular, with rounded corners. The first ones are a little longer than wide. Then they become as long as they are wide. They are contiguous all along the length of the adjacent edges.

The lateral plates are not very prominent. They have four cylindrical spines, thick and strong, with an obtuse end except the first ventral that is rather pointed. Their length equals that of the article. The two median spines end in two small divergent points more-or-less developed.

The tentacular scale is rather large and oval.

Similarities and Differences. A. velox belongs, like the preceding species, to the group of Amphiura s. str. with scales on both sides of the disk and having a single tentacular scale. It is near the species discovered by the "Siboga" in the adjacent areas and that I have described under the names of A. abbreviata, agitata, celata and coacta, but is distinguished from them by the form of the buccal shields, by the number of brachial spines and especially by the number of arms. It is also separated from A. ficta that I have just studied by the number of brachial spines, by its size and finally by the number of arms. It recalls A. angularis Lyman by the buccal pieces and the number of brachial spines but it separated from them by the more elongated and finer radial shields by the ventral surface entirely covered with scales and finally by the number of arms.

\section{Amphiura accedens nov. sp. (PI. XV, fig. 4 and 5.)}

Dredging No. 13. 9 April 1909. Sungi Barkai. Depth 15 m. Three specimens.

The individuals are all of very small size. In the largest, the diameter of the disk is $2.5 \mathrm{~mm}$ and in the two others, it does not pass $2 \mathrm{~mm}$. In one of these latter, the dorsal surface of the disk is torn off. The arms are incomplete. Their length should reach 10 to $12 \mathrm{~mm}$.

The disk is rounded, more-or-less depressed in the interradial spaces. The dorsal surface is a little concave at the origin of the arms. It is covered with rather large plates, imbricated, all having nearly the same dimensions. We distinguish a rosette of six primary plates, very large and rounded, the radials a little smaller than the centro-dorsal and separated from it by some row of plates. The radial shields are small and short, triangular, with the extern side convex and the proximal corner rounded. They are two times longer than wide, near each other but not contiguous by their external corner, a little divergent inside and separated by a row of plate. Their length les than a third of the radius of the disk.

The ventral surface of the disk is completely covered by fine and imbricated plates. The genital slits are narrow.

The buccal shields are triangular, with rounded corners and a very convex distal edge making a more-or-less marked projection into the interradial space. They are a little wider than long. The adoral plates, of medium size, are thin inside and widened outside. The oral plates are short and 
wide. The buccal papillae are two in number. The external papilla is spiniform, effect, obtuse at the end. The internal papilla is mediocre in development. In addition, at the union of this latter and the oral plate on an upper plane is a small conical and short papilla.

The dorsal brachial plates are extremely large, with a narrow proximal edge, a very large and convex distal edge connects by rounded corners to the lateral edges. They are nearly circular.

The first ventral brachial plate is elongated and narrow, strongly narrowed outside between the corresponding adoral plates and a little widened inside. the following ones are quadrangular with the corners rounded, a little longer than with and contiguous all along the adjacent edges.

The lateral plates, rather prominent, have at first six, then five spines. These are subequal and equal to the particle, rather thick, with an obtuse end and with some very fine spinules, except on the first ventral. Two of them often develop on the middle spines in a way to make them bihamulated.

The single tentacular scale is narrow and elongated.

Similarities and Differences. A. accedens belongs, like the two preceding species, to the section of Amphiura s. str. having scales on the two surfaces of the disk and a single tentacular scale. It is very near $A$, ficta, but it is distinguished from it by the larger dorsal plates of the disk, the presence of distinct primary plates, shorter radial shields and equal brachial spines, the first ventral not being longer than the others. A. accedens is also distinguished from A. Duncani that has small radial shields, narrow and elongated, the middle brachial spines longer than the others and the wide and rounded tentacular scale.

\section{Ophiacantha decora Koehler.}

Dredging No. 8. 31 March 1908. Meriri. Depth 6-10 m. One specimen. Dredging No. 17. 5 May1908. Sungi Manumbai. Depth 5 m. Two specimens.

The specimens conform well to the type that was discovered by the "Investigator" in Ceylon, at the Andamans and at Pile Torres.

\section{Ophiothrix expedita Koehler.}

Dredging No. 16. 16 April 1908. Udjir. Depth 10-14m. Six specimens.

The individuals, in an excellent state of preservation, conform well to the type that I described according to specimens that the "Siboga" collect in several localities in the Sunda Islands.

\section{Ophiothrix foveolata Marktanner-Turneretscher.}

See for the bibliography:

Koehler, 1905. Siboga Bxpeditie. Les Opbiures littorales, p. 76.

Dredging No. 3. 20 Marchs 1908. Wokam. Depth 16 m. One specimen.

Dredging No. 16. 16 April 1908. Udjir. Depth 10-14 m. Three specimens. 


\section{Ophiothrix galatheae Lütken.}

Dredging No. 11. 3 April 1908. Pulu Bambu. Depth 10 m. One specimen.

\section{Ophiothrlx longipeda (Lamarck).}

Dredging No. 16. 16 April 1908. Udjir. Depth 10-14 m. One small specimen.

\section{Ophiothrix Martensi Lyman.}

Dredging No. 5. 30 April 1908. Karang Guli. Depth 8-10 m. One small specimen. Dredging No. 16. 16 April 1908. Udjir. Depth 10-14m. Five specimens.

\section{Ophiothrlx Nereidina Lamarck.}

Dredging No. 3. 19 March 1908. Wokam. Depth 16 m. Four specimens.

Dredging No. 4. 19 March 1908. Wammer. Depth $50 \mathrm{~m}$. Two small specimens.

Dredging No. 16. 16 April 1908. Udjir. Depth 10-14 m. Several specimens.

\section{Ophiothrix stelligera Lyman.}

Dredging No. 2. 19 February 1908. Ngaiboor. Depth $14 \mathrm{~m}$. One specimen.

Dredging No. 3. 19 February 1908. Wokam. Depth 16 m. Five specimens.

Dredging No. 4. 19 February 1908. Wammer. Depth $40 \mathrm{~m}$. Three specimens.

Dredging No. 11. 3 April 1908. Pulu Bambu. Depth 10 m. Several small specimens.

Dredging No. 17. 5 May 1908. Sungi Manumbai. Depth 20 m. Several specimens.

\section{Ophiocampsis pallucida Duncan.}

Dredging No. 9. 1 April 1908. S.W. of Lola Island. Depth 8-10 m. Several specimens.

Dredging No. 16. 16 Aprill 1908. Udjir. Depth 10-14 m. Five specimens.

\section{Ophiocampsis inermis Koehler.}

Nuhu-Tawun (Kei Islands). Two specimens.

I have described this species according to specimens collected by the "Siboga" at Banda and at anchorage at Tual (Kei Islands) 


\section{Euryale Studeri Loriol.}

See for the bibliographoy:

Koehler, Revision des Ophiures du Museum d'Histoire Naturelle. Bulletin Scientifiqiue, vol. XLI, p. 350.

Dredging No. 6. 28 March 1908. Sungi Manumbai. Depth 23 m. One specimen.

The specimen is of medium size. The diameter of the disk does not pass $30 \mathrm{~mm}$. It conforms well to the description of de Lorol.

I have discussed, in the work cited above, the relation of E. Studeri and E. aspera Lamarck.

Lyon, September 1909. 


\section{Plate XV.}

Fig. 1. Luidia maculata. Dorsal surface. Magnification 1.3.

Fig. 2. Luidia maculata. Ventral surface Magnification 1.8.

Fig. 3. Metrodira subulata. Dorsal surface of a dried specimen coming from the Museum of Calcutta. Magnification 2.

Fig. 4. Amphiura accedens. Dorsal surface. Magnification 8.

Fig. 5. Amphiura accedens. Ventral surface. Magnification 28.

Fig. 6. Amphiura velox. Ventral surface. Magnification 20.

Fig. 7. Fromia major. Dorsal surface of a specimen with six arms. Magnification 1.3.

Fig. 8. Ophidiaster armatus. Ventral surface. Magnification 1.6. 


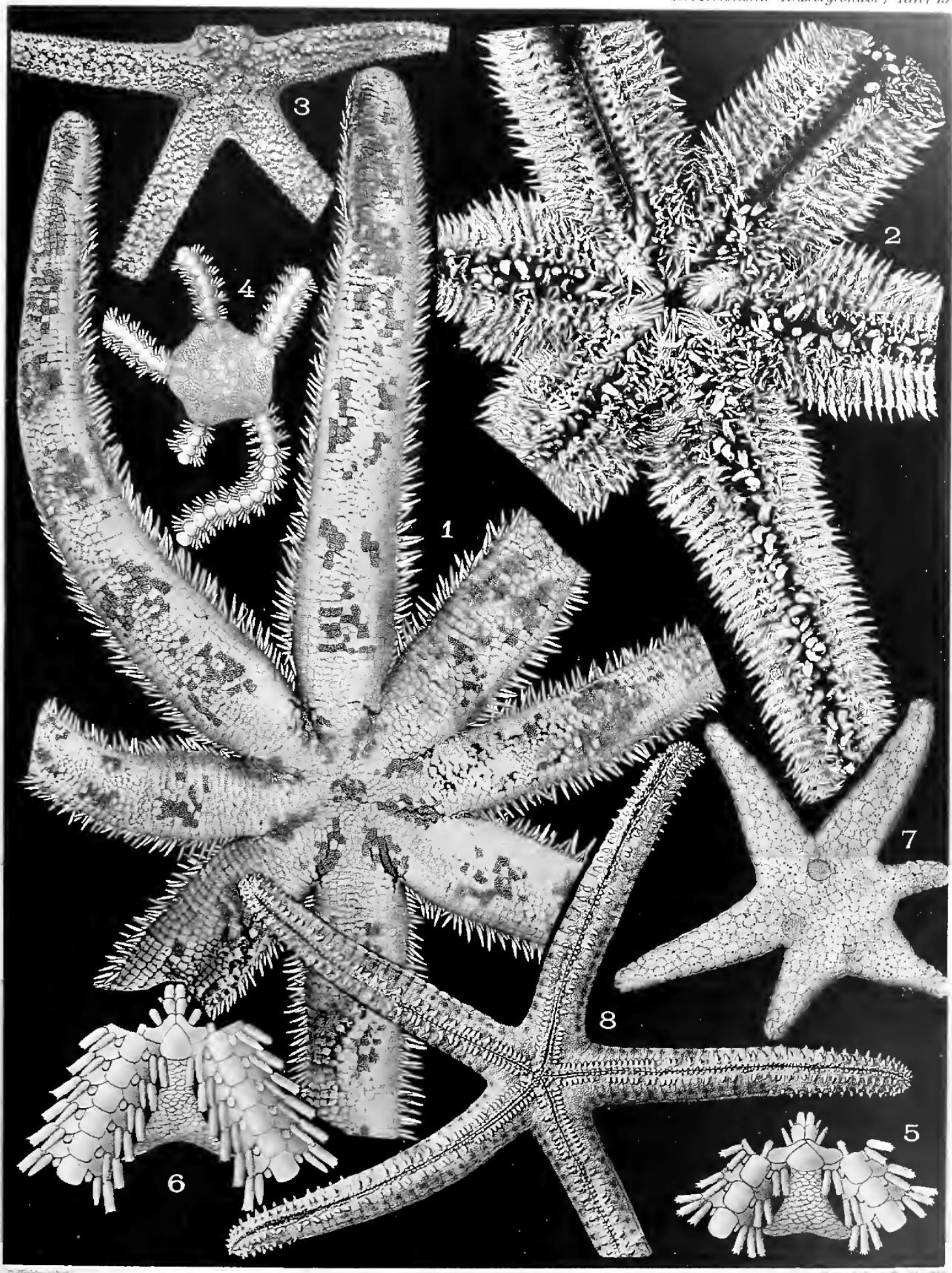

R. Koehler: Asteroidea et Ophiuroidea. 


\section{Plate XVI.}

Fig. 1. Anthenea Mertoni. Dorsal surface, slightly reduced.

Fig. 2. Anthenea Mertoni. Ventral surface, slightly reduced.

Fig. 3. Ophidiaster tumescens. Dorsal surface. Magnified 1.6.

Fig. 4. Ophidiaster tumescens. Ventral surface. Magnified 1.6.

Fig. 5. Amphiura velox. Dorsal surface. Magnified 7.

Fig. 6. Fromia major. Ventral surface of an arm. Magnified 2.5.

Fig. 7. Fromia major. Dorsal surface of an arm. Magnified 2.5.

Fig. 8. Luidia maculata. Dorsal surface of an arm. Magnified 4.5.

Fig. 9. Luidia maculata. Portion of the ventral surface of an arm. Magnified 4.5. 


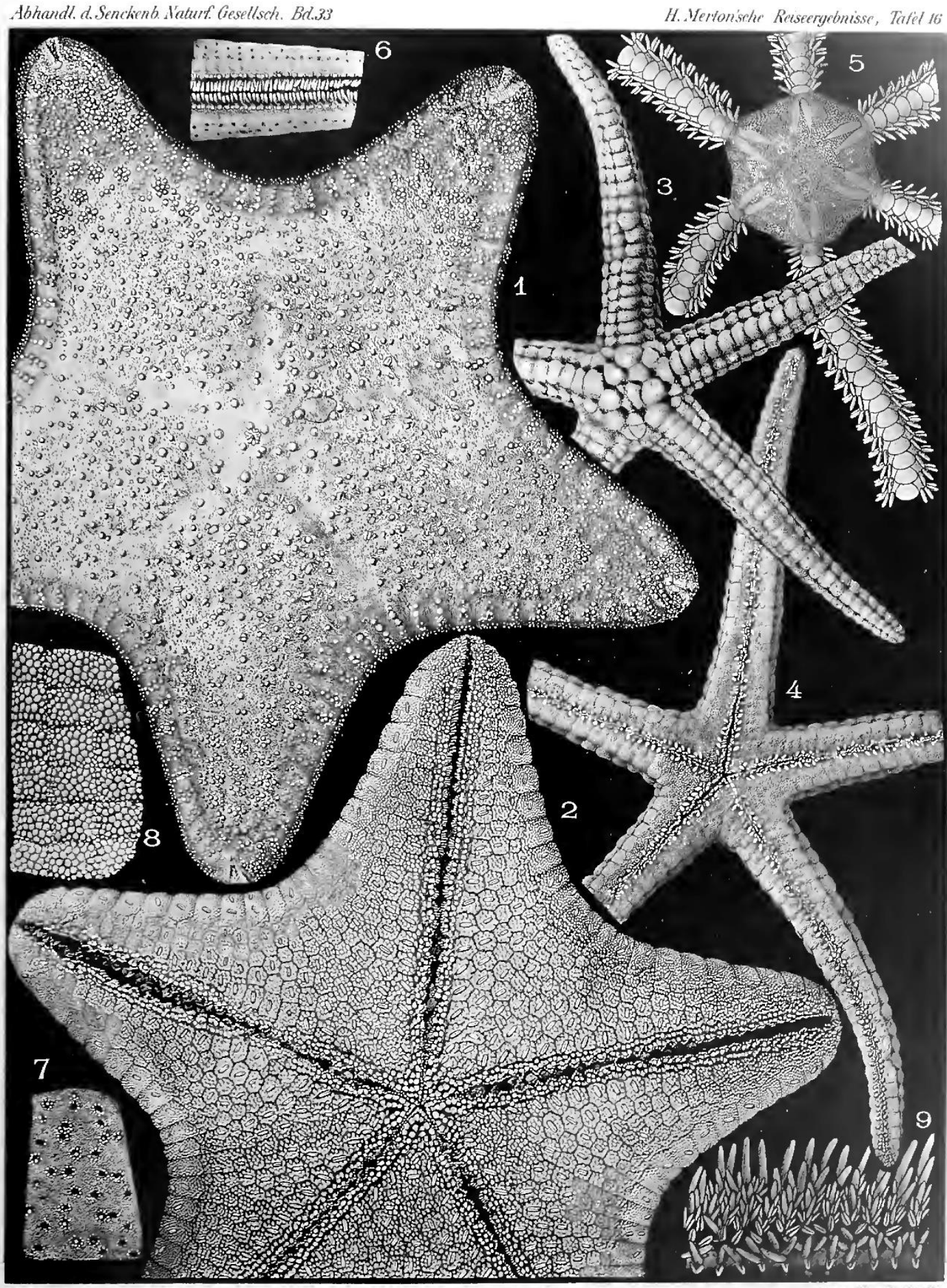

R. Koehler: Asteroidea et Ophiuroidea 


\section{Plate XVII.}

Fig. 1. Pentaceros Rouxi. Dorsal surface, very slightly enlarged.

Fig. 2. Pentaceros Rouxi. Ventral surface, very slightly enlarged.

Fig. 3. Metrodira subulata. Dorsal surface, slightly enlarged.

Fig. 4. Metrodira subulata. Portion of the dorsal surface of a dried specimen coming from the Museum of Calcutta. Magnified 5.

Fig. 5. Metrodira subulata. Ventral surface of the same specimen. Magnified 4.

Fig. 6. Ophidiaster armatus. Dorsal surface. Magnified 1.6.

Fig. 7. Linckia marmorata. Ventral surface. Magnified 2.

Fig. 8. Luidia maculata. Ventral surface of a specimen coming from the Museum of Calcutta. Magnified 2.

Fig. 9. Amphiura ficta. Ventral surface. Magnified 70.

Fig. 10. Amphiura ficta. Dorsal surface. Magnified 70. 


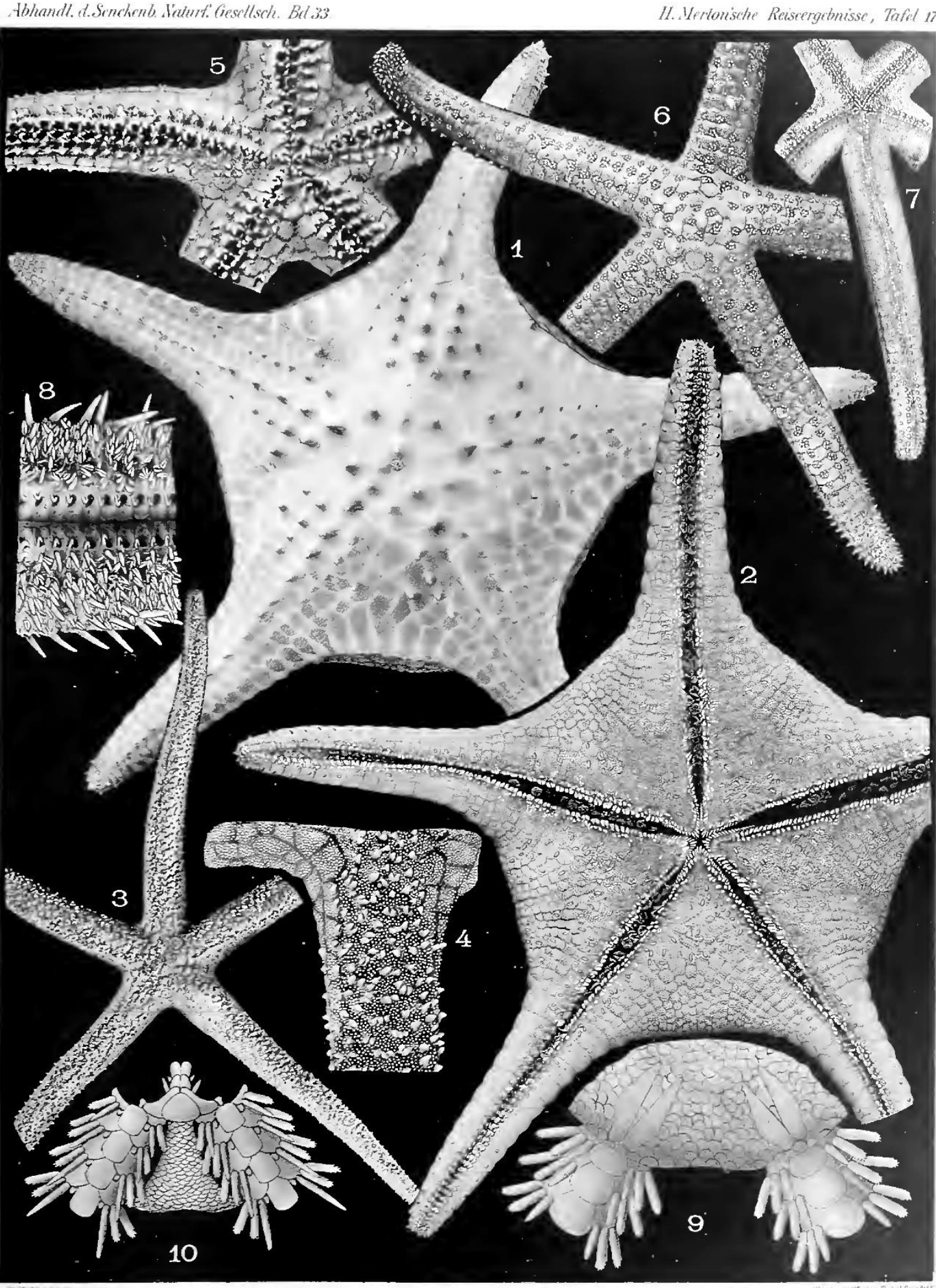

R. Koehler: Asteroidea et Ophiurondea 